\title{
Estimated durations of asymptomatic, symptomatic, and care- seeking phases of tuberculosis disease
}

Short title: Durations of asymptomatic, symptomatic, and care-seeking phases of TB

Authors

Chu-Chang Ku ${ }^{1}$, Peter MacPherson ${ }^{2,3,4}$, McEwen Khundi ${ }^{2,4}$, Rebecca Nzawa ${ }^{2}$, Helena RA. Feasey ${ }^{2,4}$, Marriott Nliwasa $^{5}$, Katherine C. Horton ${ }^{6}$, Elizabeth L. Corbett ${ }^{2,4}$, Peter J. Dodd ${ }^{1}$

1. School of Health and Related Research, University of Sheffield, United Kingdom

2. Malawi-Liverpool-Wellcome Trust Clinical Research Programme, Queen Elizabeth Central Hospital, Blantyre, Malawi

3. Department of Clinical Sciences,Liverpool School of Tropical Medicine, Liverpool, UK

4. Department of Clinical Research, London School of Hygiene and Tropical Medicine, London, UK

5. Helse Nord TB Initiative, University of Malawi College of Medicine, Malawi

6. Department of Infectious Disease Epidemiology, London School of Hygiene and Tropical Medicine, London, UK

\section{Funding statement:}

This work was supported by the Wellcome Trust (206575/Z/17/Z to PM, 200901/Z/16/Z to ELC) and the UK MRC (MR/P022081/1 to PJD). This UK funded award (PJD) is part of the EDCTP2 programme supported by the European Union. KCH is supported by the European Research Council (757699) and UK FCDO ("Leaving no-one behind: transforming gendered pathways to health for TB"). This research has been partially funded by UK aid from the UK government (to $\mathrm{KCH}$ ); however the views expressed do not necessarily reflect the UK government's official policies. 


\title{
Estimated durations of asymptomatic, symptomatic, and care- seeking phases of tuberculosis disease
}

\begin{abstract}
Ratios of bacteriologically-positive tuberculosis prevalence to notification rates are used to characterise typical durations of tuberculosis disease, but have not accounted for asymptomatic periods prior to careseeking. We developed novel statistical models to estimate progression from initial bacteriological-positivity including smear conversion, symptom onset and initial care-seeking and fitted them to tuberculosis prevalence survey and notification data (one subnational and 11 national datasets) within a Bayesian framework. Asymptomatic tuberculosis duration was in the range 4-8 months for African countries; three countries in Asia showed longer durations of $>1$ year. Care-seeking typically began half-way between symptom onset and notification. Our method also estimated smear progression rates and case-detection ratios. We found evidence for higher case-detection ratios and much shorter durations of tuberculosis for people living with HIV. To eradicate tuberculosis transmission, greater gains may be achieved by proactively screening people without symptoms through active case finding interventions.
\end{abstract}




\section{Introduction}

Population surveys of the prevalence of bacteriologically-positive tuberculosis (TB) disease are a key tool for understanding TB epidemiology and burden, and, when repeated over time, for monitoring the impacts of control efforts. Over the last decade, the World Health Organization (WHO) has encouraged and facilitated a series of nationally-representative TB prevalence surveys in priority countries [1]. TB prevalence surveys are a particularly important source of data for estimating TB incidence in high-burden settings where notification systems are imperfect [1], and while typically powered to achieve a $20 \%$ relative precision in the measurement of TB prevalence [2], surveys also contain additional information on subgroups which has, for instance, highlighted the higher burden of TB among men [3].

By comparing prevalence with notifications - usually as a prevalence-to-notification (P:N) ratio — one can estimate a typical timescale for prevalent TB, the inverse of which (the patient diagnostic rate) provides a measurable indicator of the effectiveness of case detection [4]. Comparing P:N ratios between sexes has shown men have poorer access to care in many settings [3]. However, the influence of age and HIV have not been analysed.

Several prevalence surveys also record whether individuals with TB were symptomatic and some record whether individuals with TB had previously sought care for their symptoms [5]. These surveys have found that large proportions of cases - around half—do not report symptoms [6,7]. Lack of symptoms among those with microbiologically-confirmed pulmonary TB has contributed to an increased understanding of asymptomatic and subclinical TB as being part of a spectrum of TB disease [8], and a potentially important contributor to TB burden and transmission $[7,9]$.

Many aspects of the natural history of TB disease prior to (or without) treatment remain very uncertain because ethical considerations mean we must rely on historic data from the pre-chemotherapy era. For example, how often and how quickly individuals with smear-negative TB progress to smear-positive disease is unclear. Similarly, while there are data to suggest a typical duration of around three years for untreated TB disease [10], there is only weak and indirect data to quantify the duration of TB among people living with HIV (PLHIV), which is thought to be much shorter [11].

A better understanding of the duration of asymptomatic bacteriologically-positive pulmonary TB could inform how screening, case finding, and prevention interventions are designed and implemented. We therefore sought to leverage prevalence survey data from a variety of settings to investigate the duration of asymptomatic TB disease, and typical delays to care-seeking and notification. We used a novel Bayesian framework within which we incorporated uncertainty, disease progression before detection, and trends in incidence. This approach also provided estimates of TB incidence, incidence trends, case-detection ratios, and for some settings, stratification by age and HIV infection status. 


\section{Methods}

\section{Study populations and data}

\section{TB prevalence surveys}

We analysed data from eleven national and one sub-national settings with a TB prevalence survey conducted after 2010. We excluded TB prevalence surveys that relied solely on symptom screening to decide who to sample for bacteriological testing and restricted to the population aged 15 years or older.

The eleven national settings with recent TB prevalence surveys are Cambodia [12], Ethiopia [13], Kenya [14], Lao PDR [15], Malawi [16], Pakistan [17], Philippines [18], Tanzania [5,19], Uganda[20], Vietnam [21], and Zambia [22]. For those prevalence surveys, we extracted the raw counts of eligible subjects and active cases, excluding those already on TB treatment if possible. Seven surveys included healthcare behaviour data enabling us to identify whether symptomatic cases had started seeking care.

Summaries of prevalence survey data are shown in Table 1. The proportion of prevalent cases that was asymptomatic ranged from $30 \%$ in Malawi, to $70 \%$ in Cambodia, and the proportion of prevalent cases that were sputum smear positive varied from 23\% in Vietnam to $84 \%$ in Tanzania. Definitions used for symptoms, criteria used for bacteriological testing, and bacteriological testing methods are summarized in

\section{Table 1-table supplement 1.}

The sub-national TB prevalence survey from Blantyre, Malawi and the national survey from Kenya [15] included individual data, allowing analysis by smear status, age, and HIV status [14]. In Blantyre, Malawi, the prevalence survey was conducted as part of a community cluster randomised trial across approximately 750,000 adults in 72 densely populated neighbourhoods of the city. For Blantyre, we aligned symptom definition with that of Kenya by considering cough of $>=2$ weeks, considering cough of any duration in a sensitivity analysis.

\section{Definitions}

Unless otherwise stated, we used the definition of TB symptoms and health-care seeking adopted by each TB prevalence survey. Asymptomatic TB was taken to be bacteriologically-positive pulmonary TB in those reporting no TB symptoms, and we assumed no health-care seeking for TB during this phase. Participants with prevalent TB who were already taking TB treatment were excluded. We assumed TB treatment initiation, TB confirmation, and case notification are identical events for the modelling.

\section{TB notification data}

We used TB notification data and treatment outcome data from the WHO TB database for the countries with national prevalence surveys [12-22]. We included new and relapse TB regardless of smear status since 2013. We applied the proportions of HIV among TB notifications by sex, age group, and smear status to disaggregate the WHO notification data. Where notification data exhibited level shifts suggestive of changes in reporting, only consistent, sequential data were used.

For Kenya, we obtained data simultaneously stratified by HIV and age group from the National Tuberculosis Programme. For Blantyre, we obtained individual-level notification data from an enhanced surveillance 
medRxiv preprint doi: https://doi.org/10.1101/2021.03.17.21253823; this version posted April 4, 2021. The copyright holder for this preprint

(which was not certified by peer review) is the author/funder, who has granted medRxiv a license to display the preprint in perpetuity.

It is made available under a CC-BY 4.0 International license .

system. We matched the age-groups of the Kenya data to the finest scale of WHO case notification data; for Blantyre, Malawi, with lower case counts, we used two age groups (15 to 49, and 50+ years).

\section{Demographic data}

In order to model mortality and project national numbers of prevalent cases to relate to notifications, we used age- and sex-specific background mortality rates and population sizes from 2019 World Population Prospect (WPP) data, using the mid-year population estimates [23]. For Blantyre, we rescaled the Malawi demographic data to local 2008 and 2018 population censuses [24,25].

The demographic and notification data to replicate the analysis are available at Source Data.

\section{Statistical methods}

\section{Estimation of TB progression and care-seeking behaviour}

We developed three state transition models of TB case-detection to match available data, and fitted them to estimate parameters driving TB progression and care-seeking behaviour. Figure 1 shows that all models contain an asymptomatic phase and progress to the symptomatic phase. Model A presents a basic transition between asymptomatic/symptomatic phases; Model B divides the symptomatic phase by presence of careseeking intentions, and Model $\mathrm{C}$ details the conversion between smear-negative and smear-positive and careseeking by smear status. Model B is only applicable to the prevalence surveys that reported care-seeking behaviours. We did not combine Model B and C because the symptoms, smear status, and care-seeking behaviours prevalence surveys were not cross-tabulated in the published reports. We constructed a likelihood depending on these states to fit to TB prevalence and case-notification data. For Kenya and Blantyre data with Model $\mathrm{C}$, we incorporated proportional hazard models relating the rate of symptom onset and the careseeking rates by smear status to covariates of age, sex, and HIV status.

We calculated a single weighted-mean background mortality rate from WPP data in each country, using WHO TB notifications as weights. For the analyses with HIV stratification, we added HIV-related deaths for PLHIV from the UNAIDS database: 0.016 per year $(21,000$ / 1,300,000) for Kenya in 2016 and 0.011 per year $(11,000 / 1,000,000)$ for Blantyre (based on Malawi data). In asymptomatic TB, we assumed no TBrelated deaths, but did allow self-cure and deaths due to other causes. Smear status-specific TB death rates were applied to symptomatic TB states based on Tiemersma et al. [10]. For Model A and Model B, regardless of smear status, we applied the untreated TB deaths weighted by smear status in the notification data. We conducted sensitivity analyses for assumed excess mortality rates of asymptomatic/symptomatic TB. We also considered two extreme assumptions for HIV-TB excess mortality: the same TB mortality rate as HIV-negative people, and an excess mortality rate of 5\% per month as considered in Vynnycky et al. [26] for gold miners in South Africa.

We assumed each state steadily declined with a constant shared rate. The statistical models were constructed within a Bayesian framework; Figure 1-figure supplement 1-3 details the mathematical formulation and priors. We fitted all models by Markov chain Monte Carlo (MCMC) using R with rstan. MCMC runs all converged with Gelman-Rubin $\mathrm{R}^{\wedge} 2$ statistics < 1.05. Inferences were based on 3,000 samples from three chains after burn-in. Processed data and all source code for this analysis are available on Github as [https://github.com/TimeWz667/AsymTB.git]. 
medRxiv preprint doi: https://doi.org/10.1101/2021.03.17.21253823; this version posted April 4, 2021. The copyright holder for this preprint (which was not certified by peer review) is the author/funder, who has granted medRxiv a license to display the preprint in perpetuity.

It is made available under a CC-BY 4.0 International license .

\section{Metrics calculated}

For each setting, we used posterior samples to calculate: the TB incidence; the mean times from incident disease to development of symptoms (i.e. the duration of asymptomatic disease), to case-seeking initiation (where applicable), and to notification; the case detection ratio (CDR) as the ratio of incidence and notification rates; and the proportion of TB cases reaching each stage of care. Aggregated quantities were computed weighted by model-estimated incidence. We also output a joint posterior for the proportion of symptomatic cases initially smear positive and the subsequent smear-conversion rate. We report means and 95\% credible intervals (CrIs).

\section{Ethical approval}

The Blantyre, Malawi TB prevalence survey received ethical approval from the College of Medicine, University of Malawi, and from London School of Hygiene and Tropical Medicine. 


\section{Results}

\section{Duration of asymptomatic disease, time to care-seeking initiation and time to case-detection}

The national estimates for duration of asymptomatic disease typically ranged around 3-8 months. However, three countries in Asia (Lao PDR, Cambodia, Philippines) showed longer durations of over one year (see

Figure 2). These countries also had long total durations: 22 months for Cambodia and Philippines, and three years for Lao PDR. Only one country (Ethiopia) had a total duration lower than 12 months. In the seven countries where we could estimate the delay to care-seeking initiation, apart from the Philippines (16 months), delay varied between $1.2(0.7-1.9)$ months for Cambodia and 6.6 (95\% CrI: 4.8 - 8.6) months for Malawi. The asymptomatic phase represented between $27 \%$ and $63 \%$ of time as a prevalent case, and treatment initiation occurred between $15 \%$ and $59 \%$ of the way between symptom onset and notification (or death or self-cure).

\section{Development of smear-positivity}

Figure 3 shows the joint posterior probability densities of smear conversion rates and the proportion of symptomatic cases that were smear-positive at symptom onset. Estimates of smear conversion rates were linearly related to the initial proportion of symptomatic cases that were smear-positive. Pooling weighted by TB notifications in 2019 (excluding Malawi and Vietnam as outliers) yielded a gradient of 0.239 years, and a pooled intercept of $53.4 \%$ smear positive (for zero smear conversion rate).

\section{Estimates of epidemiological indices considering asymptomatic phase of TB}

Table 1 shows the empirical estimates of total duration and total asymptomatic duration based on P:N ratios. Empirical estimates of duration systematically overestimate the durations, because they implicitly assume all episodes of TB disease end in notification. Modelling self-cure and death leads to shorter estimates of duration and differences in estimated CDRs from WHO estimates. The proportions of incident TB who die or self-cure before being detected are shown in Table 1. Estimates of TB incidence are also distinct but comparable to WHO incidence estimates. We estimated rates of TB incidence change from a decline of $7.3 \%$ (95\% CrI: $7.1 \%-7.5 \%$ ) per year in Ethiopia up to an increase of $8.3 \%$ (95\% CrI: 8.2\% - 8.4\%) per year in the Philippines.

\section{Care-seeking cascade estimates}

Figure 4 shows care cascade estimates for the year of national prevalence surveys, showing the proportion of incident TB cases that develop symptoms, begin seeking care, initiate treatment, and finally successfully complete treatment. There were notable differences between countries, with the proportion initiating TB treatment ranging from 30\% (95\% CrI: $24 \%$ - 38\%) in Lao PDR to 83\% (95\% CrI: $72 \%-88 \%$ ) in Ethiopia. Versions of these figures with cohort timings are shown in Figure 4-figure supplement 1.

\section{Sex, age, and HIV}

For Kenya and Blantyre, Malawi, we were able to examine results stratified by sex, age, and HIV-status (see Table 2). For Kenya we found total durations of 18.8 months (95\% CrI: $16.1-21.8$ ) for men and 15.4 months (95\% CrI: 13.0 - 18.1) for women, and for Blantyre 9.9 months (95\% CrI: 6.7 - 13.8) for men and 6.6 months (95\% CrI: $3.5-10.2)$ for women, in line with previous work suggesting longer durations for men [3].

Adjusted results for Kenya suggested a longer asymptomatic phase in men than women; however, there were no clear differences in unadjusted results and results from Blantyre (see risk ratios in Table 2). There were also no clear patterns with respect to age. However, HIV status had a strong effect, with asymptomatic and symptomatic durations being shorter in PLHIV than those that were HIV negative. The total duration in PLHIV was 3.7 months (95\% CrI: 1.9 - 6.0) for Blantyre and 7.8 months (95\% CrI: 5.8 - 10.2) for Kenya. 
medRxiv preprint doi: https://doi.org/10.1101/2021.03.17.21253823; this version posted April 4, 2021. The copyright holder for this preprint (which was not certified by peer review) is the author/funder, who has granted medRxiv a license to display the preprint in perpetuity.

It is made available under a CC-BY 4.0 International license .

We found that CDRs were consistently higher in PLHIV than in those without HIV infection, even with higher deaths rates for PLHIV with TB assumed (Table 3).

Without HIV-specific case notification data at the national scale, Figure 5 demonstrates the relationship between the asymptomatic duration estimates and the PLHIV among case-notification. We found no clear pattern of the association.

\section{Sensitivity Analyses}

Across all mortality scenarios considered, differences in duration were around one month, except for Lao PDR (Table 4). The highest levels of assumed mortality led to up to a 7 percentage-point lower casedetection ratio than for the lowest assumed mortality. Sensitivity analysis assuming an extremely high excess TB mortality for PLHIV (Table 3 and Table 4-table supplement 2) led to up to 15 percentage-point lower CDRs and correspondingly higher incidence rates. However, for both Kenya and Blantyre, the case-detection ratios were still not lower than that of HIV negative populations. Considering a broader range of symptoms resulted in shorter durations of the asymptomatic phase but longer time-spent on care-seeking given the TB prevalence survey and notification data (Table 4-table supplement 3). 


\section{Discussion}

By calibrating simple models of TB disease and care-seeking progression to prevalence survey and notification data, we were able to infer the typical duration of asymptomatic bacteriologically-positive TB to be around six months. However, there is large variation between settings, with longer durations of asymptomatic disease in the included Asian settings. The asymptomatic phase typically comprised around half the total time before notification. For countries that reported care-seeking history in their prevalence surveys, we were able to estimate the average timing of initial care-seeking, finding this was approximately halfway between symptom onset and ultimate diagnosis. We found limited evidence of age-dependence in overall durations, with a hint of longer durations in older age groups, but did find substantially shorter disease durations in people living with HIV. Our analysis of TB care-seeking, diagnosis and treatment outcome cascades also showed substantial differences between settings, and meaningful losses before symptom onset and care-seeking. Taken together, these findings suggest that important opportunities exist to identify people with tuberculosis earlier in their disease course through screening and community-based active case finding interventions, potentially improving individual outcomes and reducing transmission.

TB disease prior to care-seeking, including the asymptomatic phase, is beyond the reach of passive casefinding: improvements in diagnosis and retention at the clinic will not shorten these delays nor avert deaths during this phase. Cases who are truly asymptomatic can only be found by active approaches to screening based on exposure, chest X-ray or other novel rule-in tests - based in either the community or clinics. The symptomatic period prior to care seeking would be amenable to intervention by symptom-based screening approaches and potentially health-messaging or improved access to care. Understanding the duration of these phases and their contributions to transmission and mortality is therefore key to understanding the relative potential benefits of more active approaches to finding cases [27]. Although, between $25 \%$ and $50 \%$ of the total duration (and likely a higher proportion of transmission and pre-treatment mortality) occurs once those with TB have started seeking care, when improvements in passive case-finding and reductions in pretreatment loss-to-follow-up (which has been observed a 13\% in Asia and 18\% in African settings) can help [28]. While there is considerable consistency between settings in our results, the reasons for the longer durations of asymptomatic disease in Asian settings are not clear, and seem not to directly relate to HIV prevalence. These may include cultural factors around recognition of disease or willingness to report it, differences in strains, or differences in cough associated with smoking or air quality which may mask TB symptoms. It is noteworthy that these settings also have longer total durations of TB disease.

Our method also generates estimates of TB incidence: using literature estimates of TB disease mortality and self-cure rates, we inferred the proportions that fail to reach notification. Our incidence estimates are similar to those of WHO, which is not surprising since these are based on the same data. Our estimates have lower uncertainty, which may reflect under-estimation of uncertainty by our approach in not including uncertainty in TB mortality rates.

Our approach has quantified aspects of TB natural history that are potentially important but poorly characterised, relying on historical or anecdotal data. For example, mathematical models of TB transmission have from the outset often included progression in smear status [29]. In analysis of cross-sectional data, this smear conversion rate is confounded with the proportion of individuals who are smear-positive from very early in their disease. Our posterior shows high correlation between these parameters, but the gradient of 
initial smear-positivity with respect to conversion rate is broadly consistent between settings. Our pooled estimate should be useful for modellers wishing to parametrize joint uncertainty around these features.

There has been an increased realisation that TB disease is less dichotomous and more dynamic than conventional paradigms have allowed [8]. Our findings complement work in this area by describing the dynamics through asymptomatic disease and different levels of infectiousness while symptomatic. (We have used the term asymptomatic TB as synonymous with the term sub-clinical TB used in some discussions.) The substantial fraction of time spent asymptomatic means there is the potential for this phase to make important contributions to TB transmission; the key unknown factor being the relative infectiousness of the asymptomatic phase [9]. While some evidence suggests that the natural history of TB disease may include progression and remission [8], we have assumed a one-way progression through the asymptomatic phase, smear status, and care-seeking - we were limited here by our reliance on cross-sectional data. However our transitions between these cruder states could be considered as characterising the net average transitions in a population experiencing more complex dynamics among sub-states. Similarly, there may be heterogeneity in disease-course, which we were not able to consider.

HIV-associated TB has long been known to have a more rapid TB disease progression, but data to quantify this has been limited, and most models and estimates of TB burden assume the same case detection ratio in PLHIV as among HIV-negative people. We were able to provide the first empirical estimate of this quantity. Our sensitivity analysis considered from zero excess TB/HIV mortality through to an extremely high level, and consistently found TB case-detection ratios for PLHIV that were higher than for HIV-negative people. We were not able to stratify by ART status, but increases in ART coverage and regular healthcare visits for people on ART may have helped improve TB case detection among PLHIV. We found an asymptomatic TB disease duration shorter than five months in people living with HIV, and the delays from symptom onset to case-detection also much shorter than those for HIV-negative people.

Comparing our model estimates of the delays from TB onset to notification with empirical estimates from $\mathrm{P}: \mathrm{N}$ ratios, we find that empirical estimates systematically overestimate duration. This is because the empirical estimator implicitly assumes that all prevalent TB ends in notification, whereas in the model (and reality) self-cure and death are possible outcomes. These unobserved competing events add to the rate at which individuals cease being prevalent, thus shortening the prevalent duration. The discrepancy between empirical and model estimates is largest where the CDR is lowest. Under-notification, e.g. in settings with large private sectors can further overestimate durations.

The duration of symptomatic TB is necessarily shorter than the total duration. Empirical estimates of TB duration based on TB prevalence surveys that used symptoms as an entry point to bacteriological testing may therefore be biased. Where symptoms alone are used to rule-in, the empirical P:N ratio is measuring the duration of the symptomatic phase rather than the total duration of TB disease. The range of symptoms used can also affect estimated durations, with broader definitions shortening the duration of asymptomatic phase. All the surveys we used either applied bacteriological testing to everyone, or used chest X-ray (potentially OR symptoms) to rule-in for bacteriological testing.

A limitation of our approach is that it relies on self-report for defining whether individuals have symptoms or have begun seeking care. Stigma, fear of diagnosis, or expectations of treatment may all affect and influence participants' willingness to report symptoms, even if they are recognised; recognition of symptoms may itself be influenced by cultural and epidemiological factors [30,31]. Recall bias may play a role in limiting the accuracy of reports of care-seeking. We were limited in our ability to detect effects that may be real, such as age-dependence in durations, and to investigate smear-status while asymptomatic, due to the relatively small 
medRxiv preprint doi: https://doi.org/10.1101/2021.03.17.21253823; this version posted April 4, 2021. The copyright holder for this preprint (which was not certified by peer review) is the author/funder, who has granted medRxiv a license to display the preprint in perpetuity.

It is made available under a CC-BY 4.0 International license .

numbers of TB cases found in prevalence surveys. Our projections of growth or decline rely solely on trends in notification data; where notification trends reflect changes in routine case finding performance, our projections of underlying incidence and prevalence trends may be incorrect. Finally, while most of our parameters have incorporated prior uncertainty, being treated as random variables in a Bayesian framework, we treated TB mortality and self-cure as fixed, which may under-estimate uncertainty in our estimates.

A strength of our approach is that we have adopted a rigorous Bayesian framework, which includes uncertainty in inputs and outputs and could easily be generalised for use on other national or subnational data. Unlike most approaches to P:N analyses, we do not make an assumption of equilibrium. Our assumption is the slightly more general and realistic constant rate of decline, which is an additional output.

Conclusion

Active approaches to TB screening and case-finding should be considered in high TB burden settings, where up to 4 to 12 months with infectious bacteriologically-positive disease is spent without symptoms, and a comparable time again with symptoms before care-seeking initiation.

\section{Acknowledgements}

For sharing additional stratified TB notification data, we would like to thank the following staff at the Division of Tuberculosis, Leprosy and Lung Disease Program (DNTLD-P), Kenya: Elizabeth Onyango (head), Aiban Rono (head of M/E section), Martin Githiomi (ICT lead).

\section{Competing interests:}

The authors have declared that no competing interests exist 


\section{References}

1. World Health Organization. Global Tuberculosis Report. 2020; Available from: https://apps.who.int/iris/bitstream/handle/10665/336069/9789240013131-eng.pdf?ua=1

2. World Health Organization. Tuberculosis Prevalence Surveys: A Handbook. World Health Organization; 2011. $305 \mathrm{p}$.

3. Horton KC, MacPherson P, Houben RMGJ, White RG, Corbett EL. Sex Differences in Tuberculosis Burden and Notifications in Low- and Middle-Income Countries: A Systematic Review and Metaanalysis. PLoS Med. 2016 Sep;13(9):e1002119.

4. Borgdorff MW. New measurable indicator for tuberculosis case detection. Emerg Infect Dis. 2004 Sep;10(9):1523-8.

5. Senkoro M, Hinderaker SG, Mfinanga SG, Range N, Kamara DV, Egwaga S, van Leth F. Health careseeking behaviour among people with cough in Tanzania: findings from a tuberculosis prevalence survey. Int J Tuberc Lung Dis. 2015 Jun;19(6):640-6.

6. Onozaki I, Law I, Sismanidis C, Zignol M, Glaziou P, Floyd K. National tuberculosis prevalence surveys in Asia, 1990-2012: an overview of results and lessons learned. Trop Med Int Health. 2015 Sep;20(9):1128-45.

7. Frascella B, Richards AS, Sossen B, Emery JC, Odone A, Law I, Onozaki I, Esmail H, Houben RMGJ. Subclinical tuberculosis disease - a review and analysis of prevalence surveys to inform definitions, burden, associations and screening methodology. Clin Infect Dis [Internet]. 2020 Sep 16; Available from: http://dx.doi.org/10.1093/cid/ciaa1402

8. Drain PK, Bajema KL, Dowdy D, Dheda K, Naidoo K, Schumacher SG, Ma S, Meermeier E, Lewinsohn DM, Sherman DR. Incipient and Subclinical Tuberculosis: a Clinical Review of Early Stages and Progression of Infection. Clin Microbiol Rev [Internet]. 2018 Oct;31(4). Available from: http://dx.doi.org/10.1128/CMR.00021-18

9. Emery J. Lessons from the population: how infectious is subclinical TB? International Journal of Tuberculosis and Lung Disease. 2020;24(10):S47.

10. Tiemersma EW, van der Werf MJ, Borgdorff MW, Williams BG, Nagelkerke NJD. Natural history of tuberculosis: duration and fatality of untreated pulmonary tuberculosis in HIV negative patients: a systematic review. PLoS One. 2011 Apr 4;6(4):e17601.

11. Corbett EL, Watt CJ, Walker N, Maher D, Williams BG, Raviglione MC, Dye C. The growing burden of tuberculosis: global trends and interactions with the HIV epidemic. Arch Intern Med. 2003 May 12;163(9):1009-21.

12. Japan International Cooperation Agency, Ministry of Health (Cambodia), National Center for Tuberculosis and Leprosy Control (CENAT) (Cambodia), Research Institute of Tuberculosis/Japan Anti-Tuberculosis Association (RIT/JATA), World Health Organization (WHO). Cambodia National Tuberculosis Prevalence Survey 2010-2011.

13. Kebede AH, Alebachew Z, Tsegaye F, Lemma E, Abebe A, Agonafir M, Kebede AJ, Demissie D, Girmachew F, Yaregal Z, Dana F, Getahun M, Fiseha Y, Meaza A, Dirse N, Timimi H, Sismanidis C, Tadolini M, Onozaki I. The first population-based national tuberculosis prevalence survey in Ethiopia, 2010-2011. Int J Tuberc Lung Dis. 2014 Jun;18(6):635-9.

14. Enos M, Sitienei J, Ong'ang'o J, Mungai B, Kamene M, Wambugu J, Kipruto H, Manduku V, Mburu J, Nyaboke D, Ngari F, Omesa E, Omale N, Mwirigi N, Okallo G, Njoroge J, Githiomi M, Mwangi M, 
Kirathe D, Kiplimo R, Ndombi A, Odeny L, Mailu E, Kandie T, Maina M, Kasera K, Mulama B, Mugi $\mathrm{B}$, Weyenga $\mathrm{H}$. Kenya tuberculosis prevalence survey 2016: Challenges and opportunities of ending TB in Kenya. PLoS One. 2018 Dec 26;13(12):e0209098.

15. Law I, Sylavanh P, Bounmala S, Nzabintwali F, Paboriboune P, Iem V, Somphavong S, Kim SJ, Sismanidis C, Onozaki I, Sebert J. The first national tuberculosis prevalence survey of Lao PDR (2010 2011). Trop Med Int Health. 2015 Sep;20(9):1146-54.

16. National Tuberculosis Control Programme (Malawi),Center for Social Research, University of Malawi, World Health Organization (WHO), Centers for Disease Control and Prevention (CDC). Malawi Tuberculosis Prevalence Survey 2013-2014.

17. Qadeer E, Fatima R, Yaqoob A, Tahseen S, Haq MU, Ghafoor A, Asif M, Straetemans M, Tiemersma EW. Population Based National Tuberculosis Prevalence Survey among Adults (>15 Years) in Pakistan, 2010-2011. PLoS One. 2016 Feb 10;11(2):e0148293.

18. the National Tuberculosis Prevalence Survey 2016 Writing Team. National Tuberculosis Prevalence Survey 2016: Philippines. Department of Health - Disease Prevention and Control Bureau;

19. Senkoro M, Mfinanga S, Egwaga S, Mtandu R, Kamara DV, Basra D, Fundikira L, Kahwa A, Shirima R, Range N, Hinderaker SG, van Leth F. Prevalence of pulmonary tuberculosis in adult population of Tanzania: a national survey, 2012. Int J Tuberc Lung Dis. 2016 Aug;20(8):1014-21.

20. Centers for Disease Control and Prevention (CDC), Makerere University School of Public Health (Uganda), National Disease Control Division, Ministry of Health (Uganda), World Health Organization (WHO). Uganda National Tuberculosis Prevalence Survey 2014-2015.

21. Nguyen HV, Tiemersma EW, Nguyen HB, Cobelens FGJ, Finlay A, Glaziou P, Dao CH, Mirtskhulava V, Van Nguyen H, Pham HTT, Khieu NTT, de Haas P, Do NH, Nguyen PD, Van Cung C, Nguyen NV. The second national tuberculosis prevalence survey in Vietnam. PLoS One. 2020 Apr 23;15(4):e0232142.

22. Kapata N, Chanda-Kapata P, Ngosa W, Metitiri M, Klinkenberg E, Kalisvaart N, Sunkutu V, Shibemba A, Chabala C, Chongwe G, Tembo M, Mulenga L, Mbulo G, Katemangwe P, Sakala S, ChizemaKawesha E, Masiye F, Sinyangwe G, Onozaki I, Mwaba P, Chikamata D, Zumla A, Grobusch MP. The Prevalence of Tuberculosis in Zambia: Results from the First National TB Prevalence Survey, 20132014. PLoS One. 2016 Jan 15;11(1):e0146392.

23. Desa UN. World Population Prospects 2019. United Nations. Department of Economic and Social Affairs. World Population Prospects 2019. 2019;

24. 2008 Malawi Population and Housing Census. National Statistical Office; 2009.

25. 2018 Malawi Population and Housing Census. National Statistical Office; 2019 May.

26. Vynnycky E, Sumner T, Fielding KL, Lewis JJ, Cox AP, Hayes RJ, Corbett EL, Churchyard GJ, Grant $\mathrm{AD}$, White RG. Tuberculosis control in South African gold mines: mathematical modeling of a trial of community-wide isoniazid preventive therapy. Am J Epidemiol. 2015 Apr 15;181(8):619-32.

27. Dowdy DW, Basu S, Andrews JR. Is passive diagnosis enough? The impact of subclinical disease on diagnostic strategies for tuberculosis. Am J Respir Crit Care Med. 2013 Mar 1;187(5):543-51.

28. MacPherson P, Houben RM, Glynn JR, Corbett EL, Kranzer K. Pre-treatment loss to follow-up in tuberculosis patients in low-and lower-middle-income countries and high-burden countries: a systematic review and meta-analysis. Bull World Health Organ. 2013;92:126-38.

29. Dye C, Garnett GP, Sleeman K, Williams BG. Prospects for worldwide tuberculosis control under the 
medRxiv preprint doi: https://doi.org/10.1101/2021.03.17.21253823; this version posted April 4, 2021. The copyright holder for this preprint (which was not certified by peer review) is the author/funder, who has granted medRxiv a license to display the preprint in perpetuity.

It is made available under a CC-BY 4.0 International license.

WHO DOTS strategy. Directly observed short-course therapy. Lancet. 1998 Dec 12;352(9144):188691.

30. Marais BJ, Raviglione MC, Donald PR, Harries AD, Kritski AL, Graham SM, El-Sadr WM, Harrington M, Churchyard G, Mwaba P, Sanne I, Kaufmann SHE, Whitty CJM, Atun R, Zumla A. Scale-up of services and research priorities for diagnosis, management, and control of tuberculosis: a call to action. Lancet. 2010 Jun 19;375(9732):2179-91.

31. Daftary A, Mitchell EMH, Reid MJA, Fekadu E, Goosby E. To End TB, First-Ever High-Level Meeting on Tuberculosis Must Address Stigma. Am J Trop Med Hyg. 2018 Nov;99(5):1114-6. 
medRxiv preprint doi: https://doi.org/10.1101/2021.03.17.21253823; this version posted April 4, 2021. The copyright holder for this preprint (which was not certified by peer review) is the author/funder, who has granted medRxiv a license to display the preprint in perpetuity.

It is made available under a CC-BY 4.0 International license .

\section{Figures}

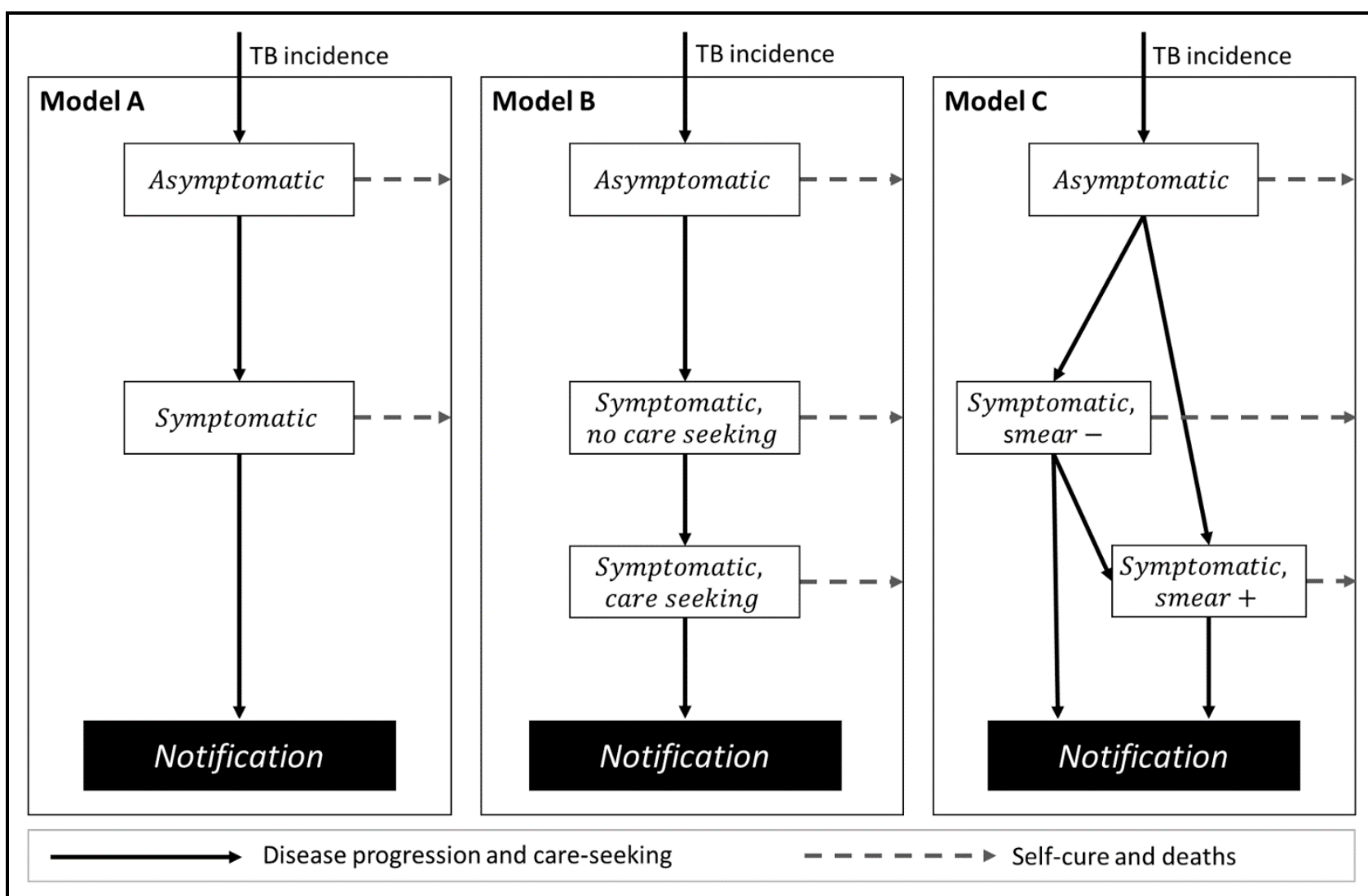

\section{Figure 1: Diagrams of model structure.}

White boxes are all bacteriologically-positive TB accessible to prevalence surveys, with structure matched to available data. Models are additionally stratified by sex, and for Kenya and Blantyre, Malawi by age and HIV in addition. 
A. State-transition diagram

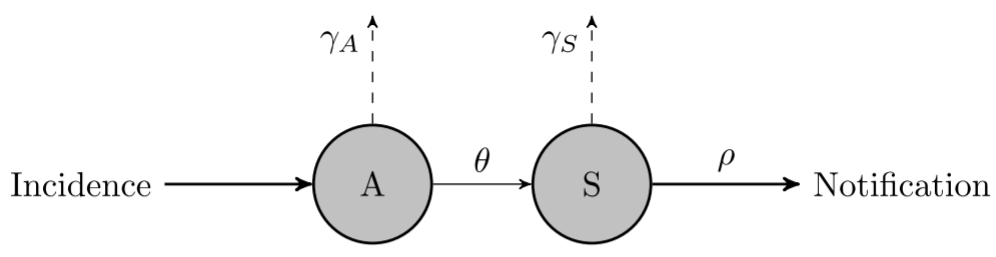

B. Steady declining condition

Prevalence

prev $_{A}=\frac{\gamma_{S}+\rho-\phi}{\gamma_{S}+\rho-\phi+\theta} \times$ Prev

prev $_{S}=\frac{\theta}{\gamma_{S}+\rho-\phi+\theta} \times$ Prev

Case notification rate (for all years, $t$ )

cnr $_{t}=\rho \times$ prev $_{S} \times e^{-\phi(t-t 0)}$
C. Empirical model

$$
\begin{aligned}
\text { Prevalent cases } \\
X_{A} \sim \operatorname{Bin}\left(N_{\text {survey }}, \text { prev }_{A}\right) \\
X_{S} \sim \operatorname{Bin}\left(N_{\text {survey }}, \text { prev }_{S}\right)
\end{aligned}
$$

Notified cases (for all years, $t$ )

Case $_{t} \sim \operatorname{Pois}\left(\mathrm{cnr}_{t} N_{\text {pop }, t}\right)$

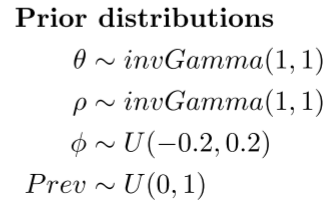

\section{Figure 1-figure supplement 1: Summary of Model A}

(A) State-transition diagram: $A$ : asymptomatic TB; $S$ : symptomatic TB. (B) steady declining condition, which has identical percentage annual decline in prevalence, incidence rate and notification rate for all states: Prev: overall active TB prevalence; $\operatorname{prev}_{A}$, prev $_{S}$ : prevalence by state; $\mathrm{cnr}_{t}$ : case notification rate at time $t$. (C) empirical model with prior distributions: $\operatorname{Bin}($.$) : binomial distribution, Pois(.): Poisson$ distribution, invGamma(.): inverse-gamma distribution, $U($.$) : uniform distribution. See Figure 1-table$ supplement 1 for the notations of parameters and data 


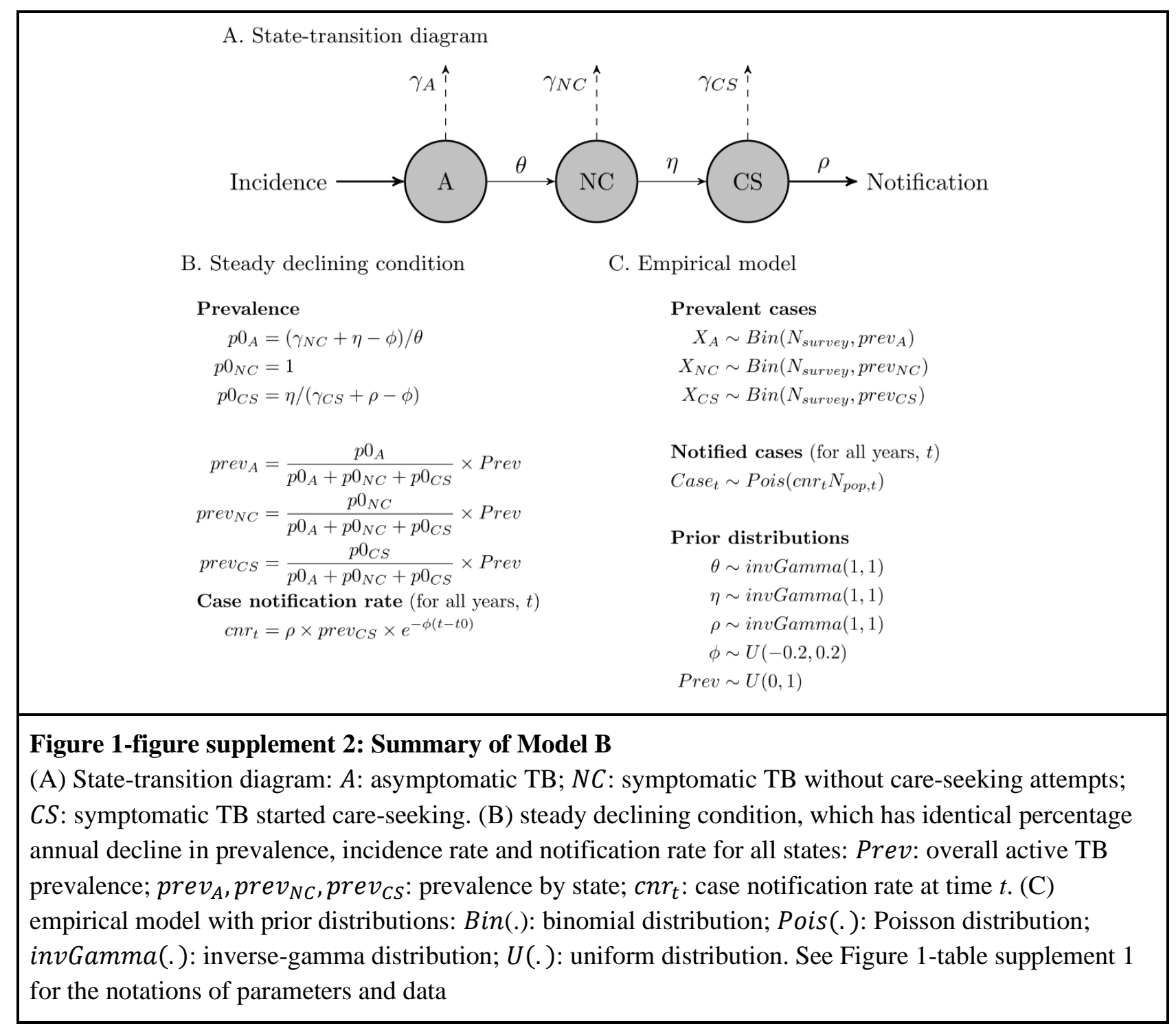




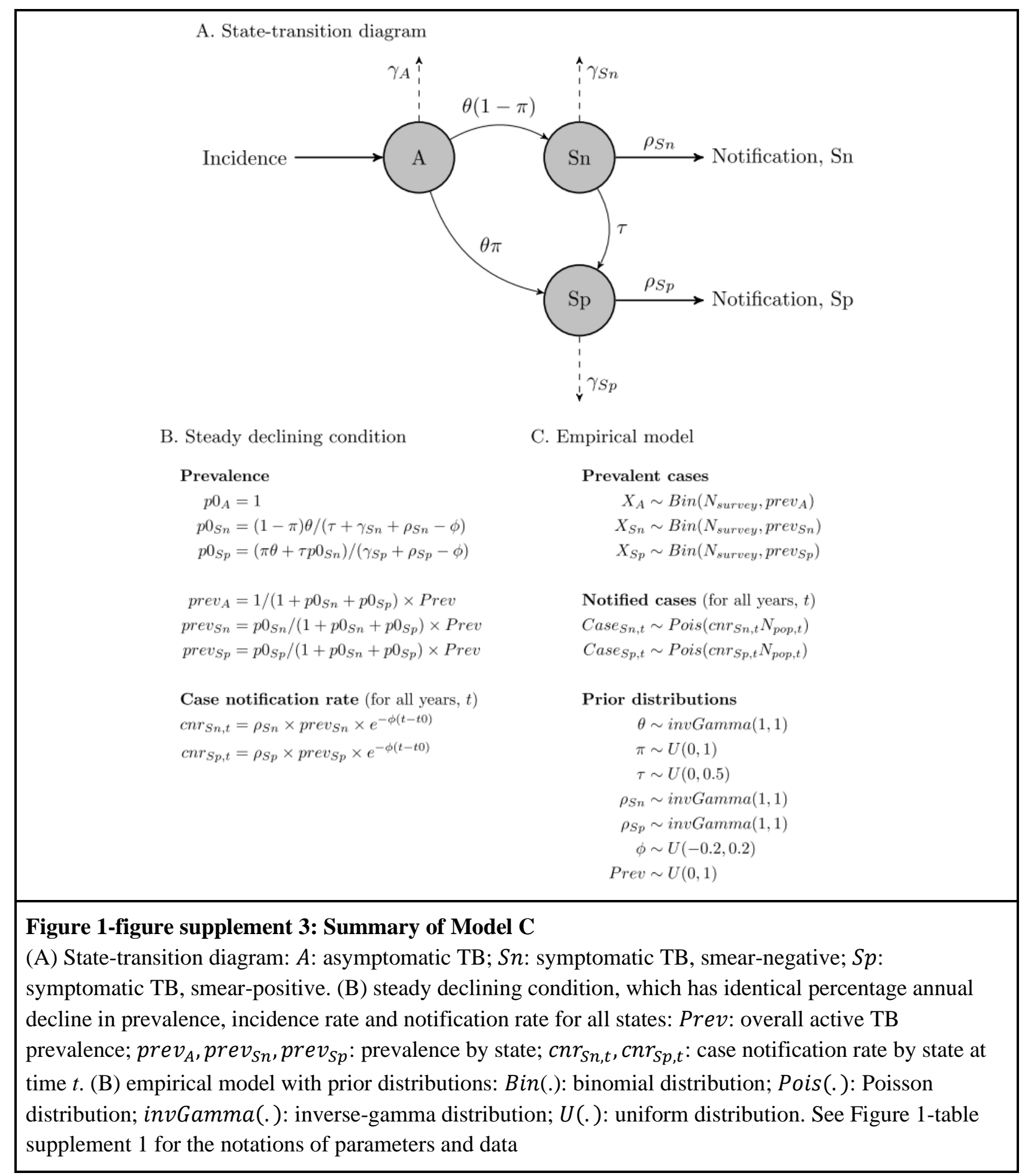


medRxiv preprint doi: https://doi.org/10.1101/2021.03.17.21253823; this version posted April 4, 2021. The copyright holder for this preprint (which was not certified by peer review) is the author/funder, who has granted medRxiv a license to display the preprint in perpetuity.

It is made available under a CC-BY 4.0 International license .

Figure 1-table supplement 1: Parameter notations and descriptions.

\begin{tabular}{|c|l|c|}
\hline Notation & Description & Prior distribution / Source \\
\hline \multicolumn{2}{|c|}{ Data } \\
\hline$X_{S}$ & Prevalent TB in state $s$ & TB prevalence surveys \\
\hline$N_{\text {survey }}$ & Eligible subjects in TB prevalence surveys & TB prevalence surveys \\
\hline$t 0$ & Year of TB prevalence surveys & TB prevalence surveys \\
\hline Case $e_{t}$ & Notified cases & WHO TB notification \\
\hline$N_{p o p, t}$ & Population size at time $t$ & WPP data \\
\hline$\mu_{s}$ & Untreated death rate of state $s \quad$ Parameters & WPP data \\
\hline & \multicolumn{2}{|c|}{ invGamma(1,1) } \\
\hline$\theta$ & Symptom onset rate & $U(0,1)$ \\
\hline$\pi$ & Proportion of smear-positive at symptom onset & $U(0,0.5)$ \\
\hline$\tau$ & Conversion rate, from smear-negative to -positive & invGamma(1,1) \\
\hline$\eta$ & Presence rate of care-seeking intentions & invGamma(1,1) \\
\hline$\rho$ & Care-seeking rate & $U(0.1,0.3)$ \\
\hline$v$ & Self-cure rate & $U(-0.2,0.2)$ \\
\hline$\gamma_{s}$ & Dropout rate before case-detection & $\gamma_{s}$ \\
\hline$\phi$ & Annual decline rate for incidence & \\
\hline
\end{tabular}

WPP: World Population Prospects 2019. invGamma(.): inverse-gamma distribution, $U($.$) : uniform$ distribution 
medRxiv preprint doi: https://doi.org/10.1101/2021.03.17.21253823; this version posted April 4, 2021. The copyright holder for this preprint (which was not certified by peer review) is the author/funder, who has granted medRxiv a license to display the preprint in perpetuity.

It is made available under a CC-BY 4.0 International license.

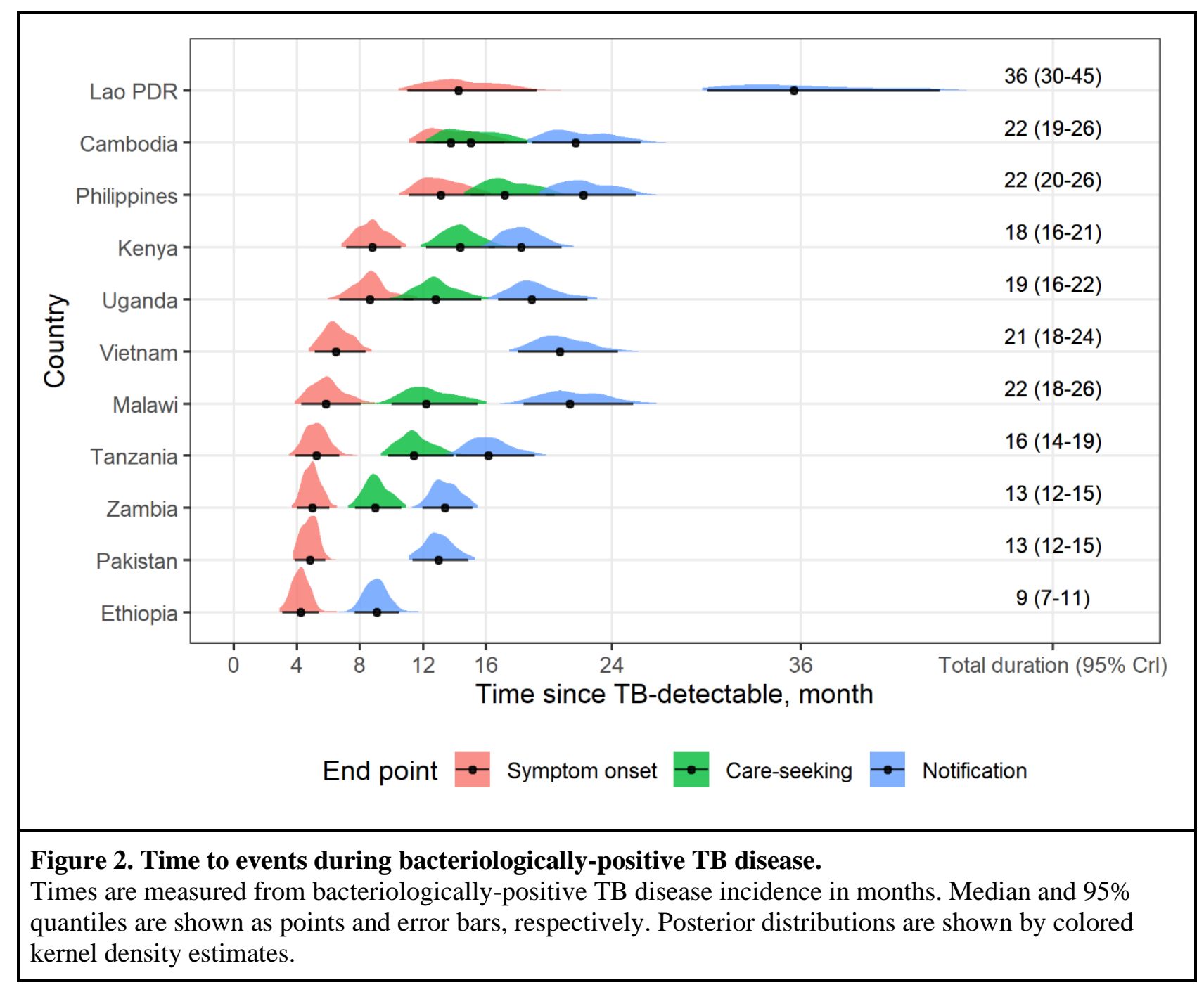


medRxiv preprint doi: https://doi.org/10.1101/2021.03.17.21253823; this version posted April 4, 2021. The copyright holder for this preprint (which was not certified by peer review) is the author/funder, who has granted medRxiv a license to display the preprint in perpetuity.

It is made available under a CC-BY 4.0 International license .

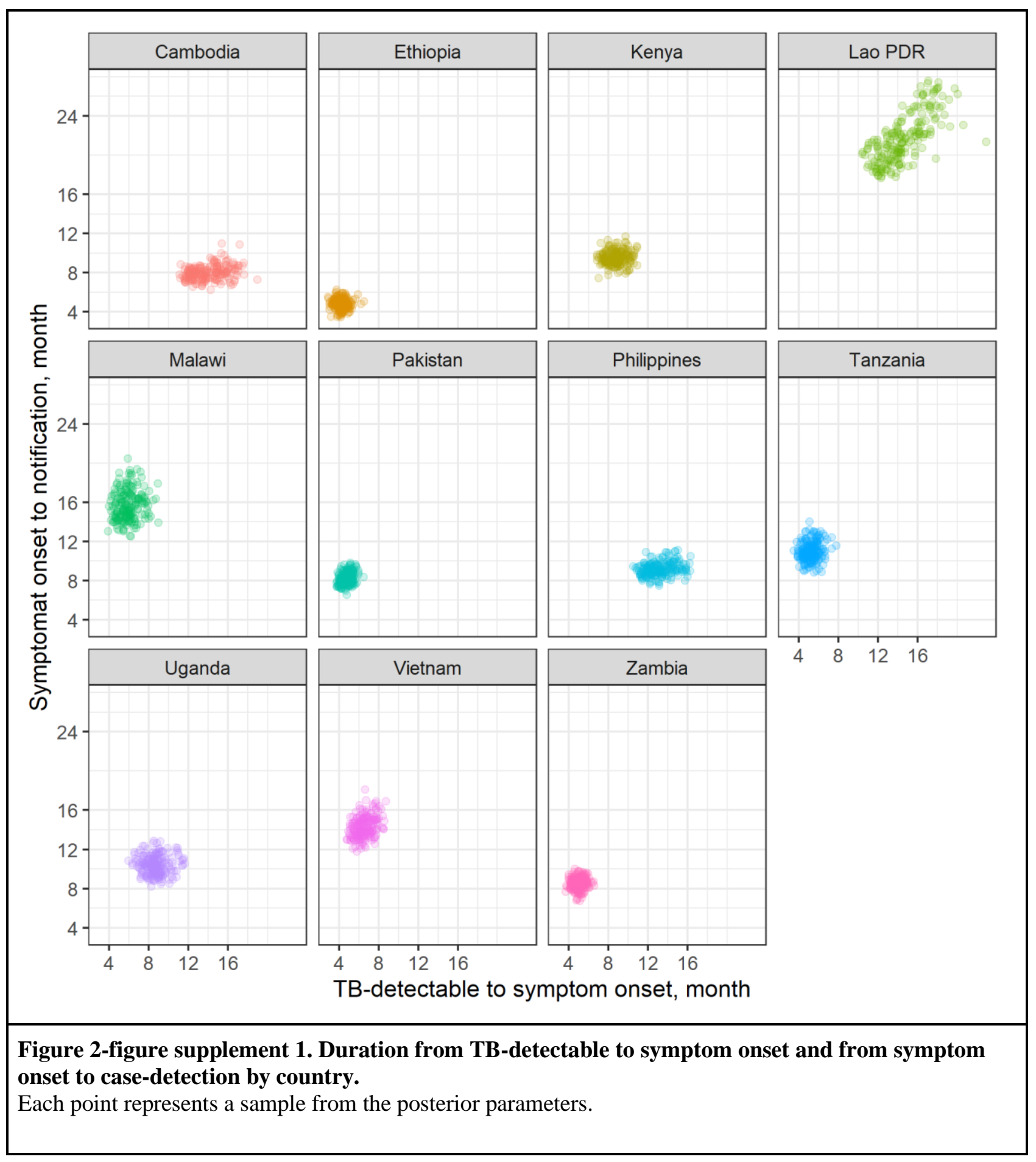


medRxiv preprint doi: https://doi.org/10.1101/2021.03.17.21253823; this version posted April 4, 2021. The copyright holder for this preprint (which was not certified by peer review) is the author/funder, who has granted medRxiv a license to display the preprint in perpetuity.

It is made available under a CC-BY 4.0 International license.

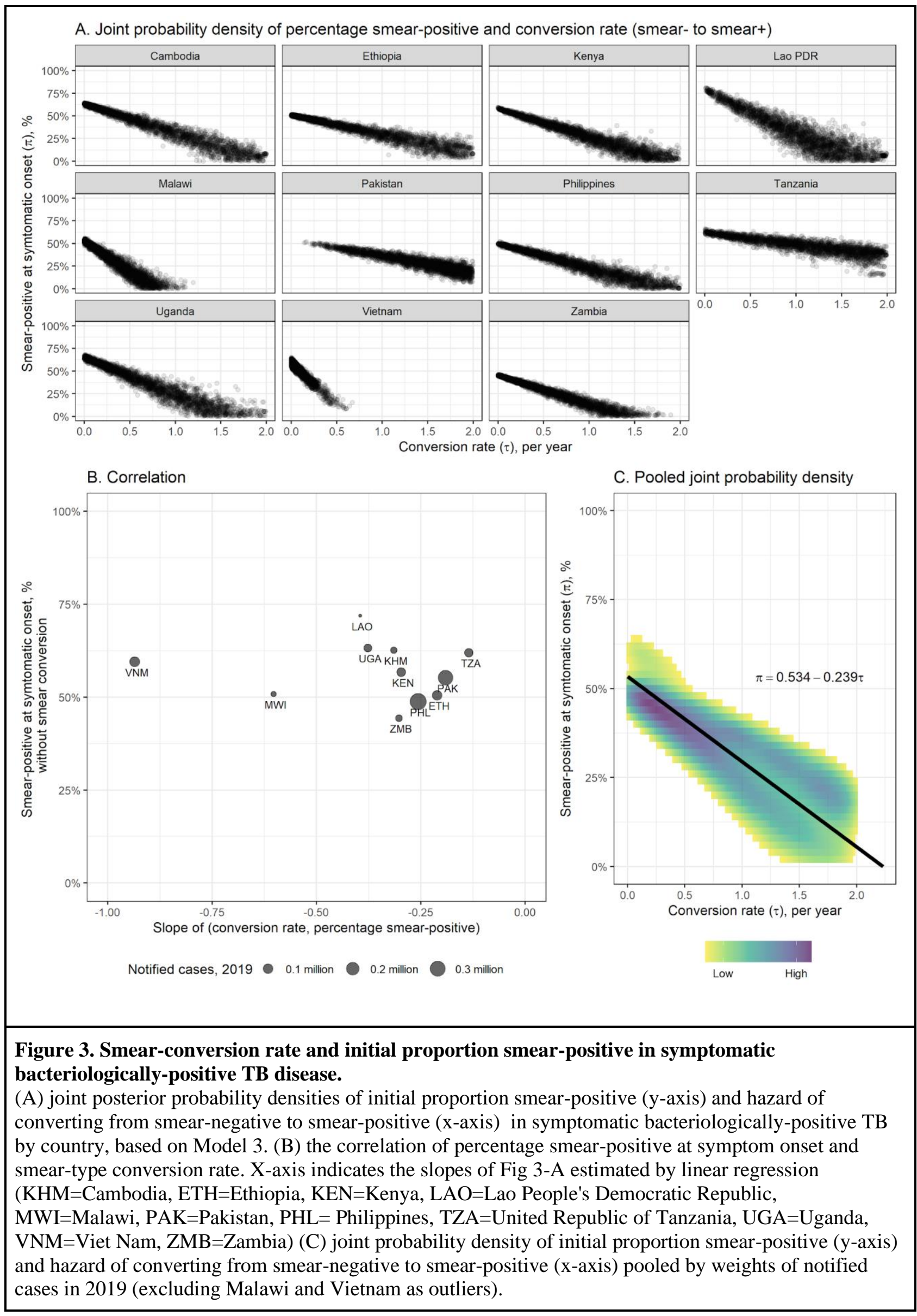


medRxiv preprint doi: https://doi.org/10.1101/2021.03.17.21253823; this version posted April 4, 2021. The copyright holder for this preprint (which was not certified by peer review) is the author/funder, who has granted medRxiv a license to display the preprint in perpetuity.

It is made available under a CC-BY 4.0 International license .

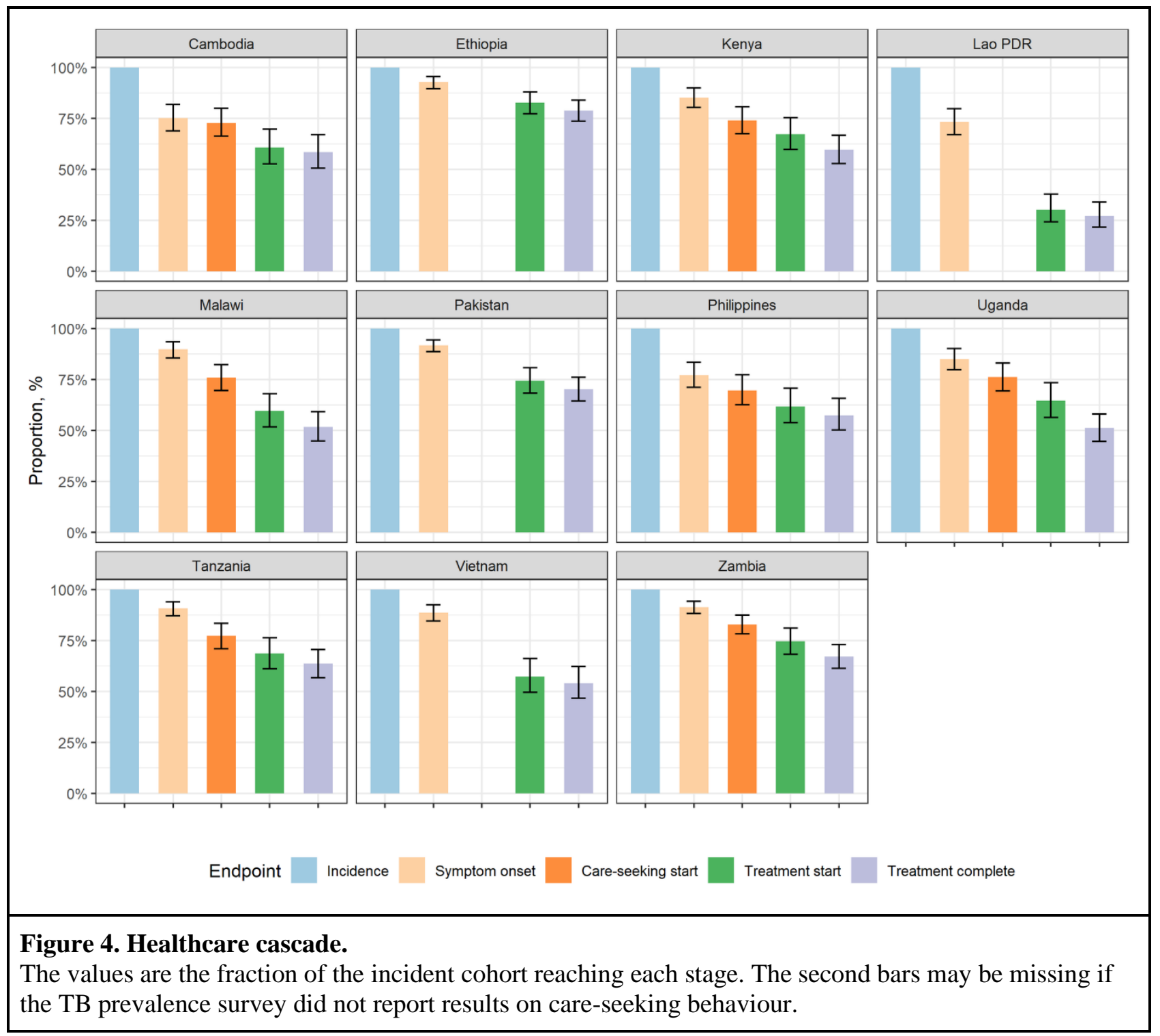


medRxiv preprint doi: https://doi.org/10.1101/2021.03.17.21253823; this version posted April 4, 2021. The copyright holder for this preprint (which was not certified by peer review) is the author/funder, who has granted medRxiv a license to display the preprint in perpetuity.

It is made available under a CC-BY 4.0 International license .

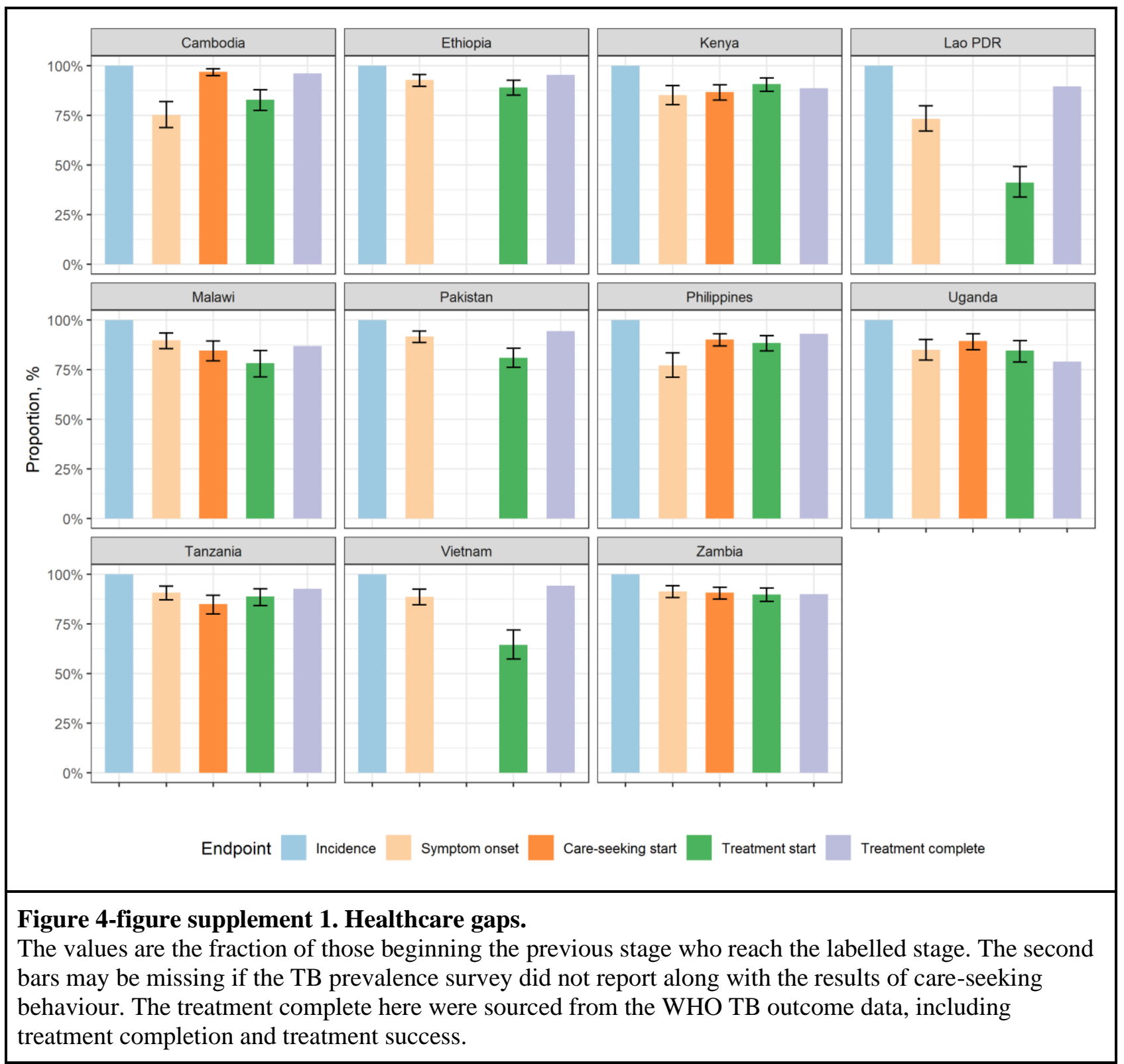


medRxiv preprint doi: https://doi.org/10.1101/2021.03.17.21253823; this version posted April 4, 2021. The copyright holder for this preprint (which was not certified by peer review) is the author/funder, who has granted medRxiv a license to display the preprint in perpetuity.

It is made available under a CC-BY 4.0 International license .

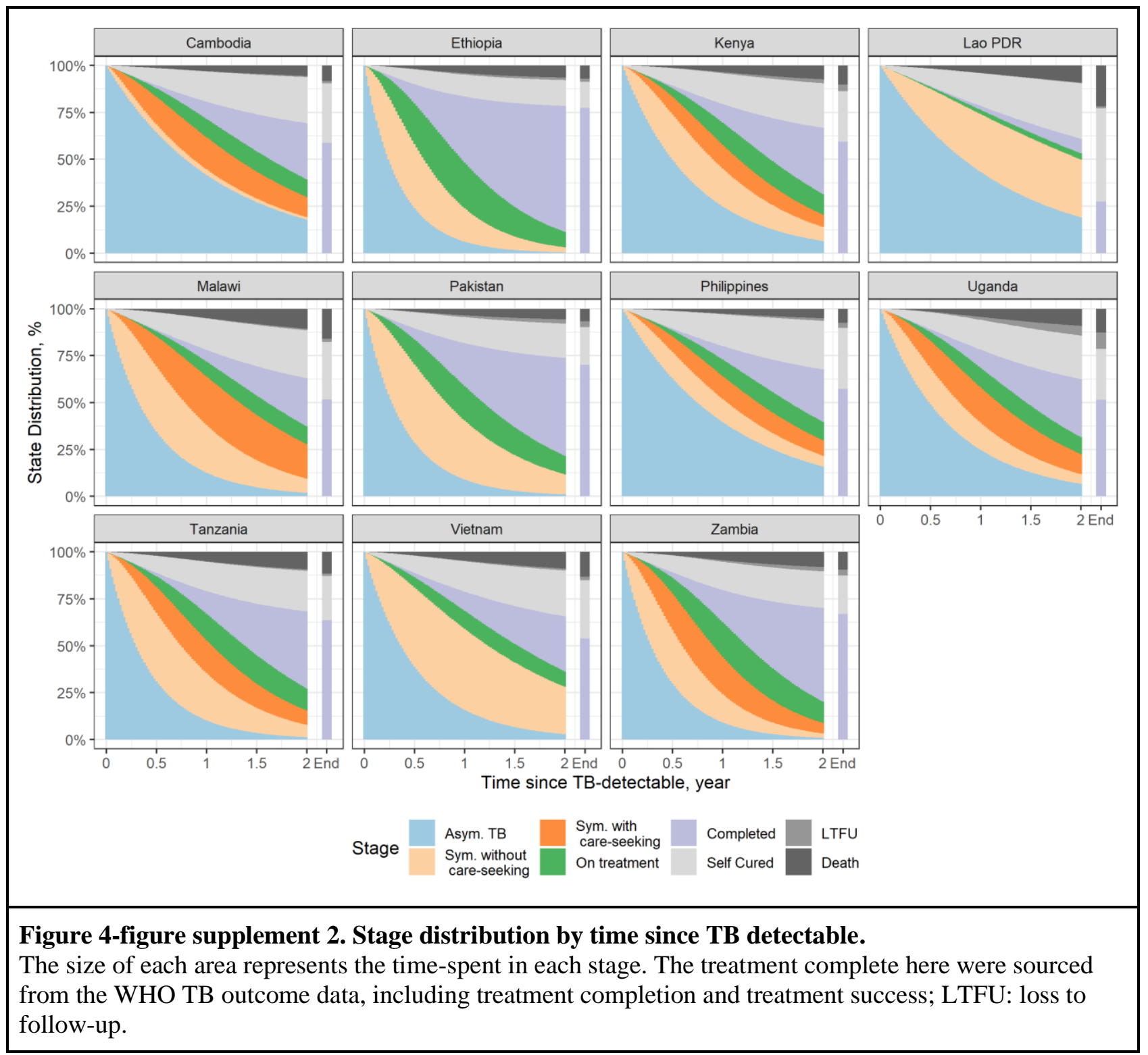


medRxiv preprint doi: https://doi.org/10.1101/2021.03.17.21253823; this version posted April 4, 2021. The copyright holder for this preprint (which was not certified by peer review) is the author/funder, who has granted medRxiv a license to display the preprint in perpetuity.

It is made available under a CC-BY 4.0 International license. 


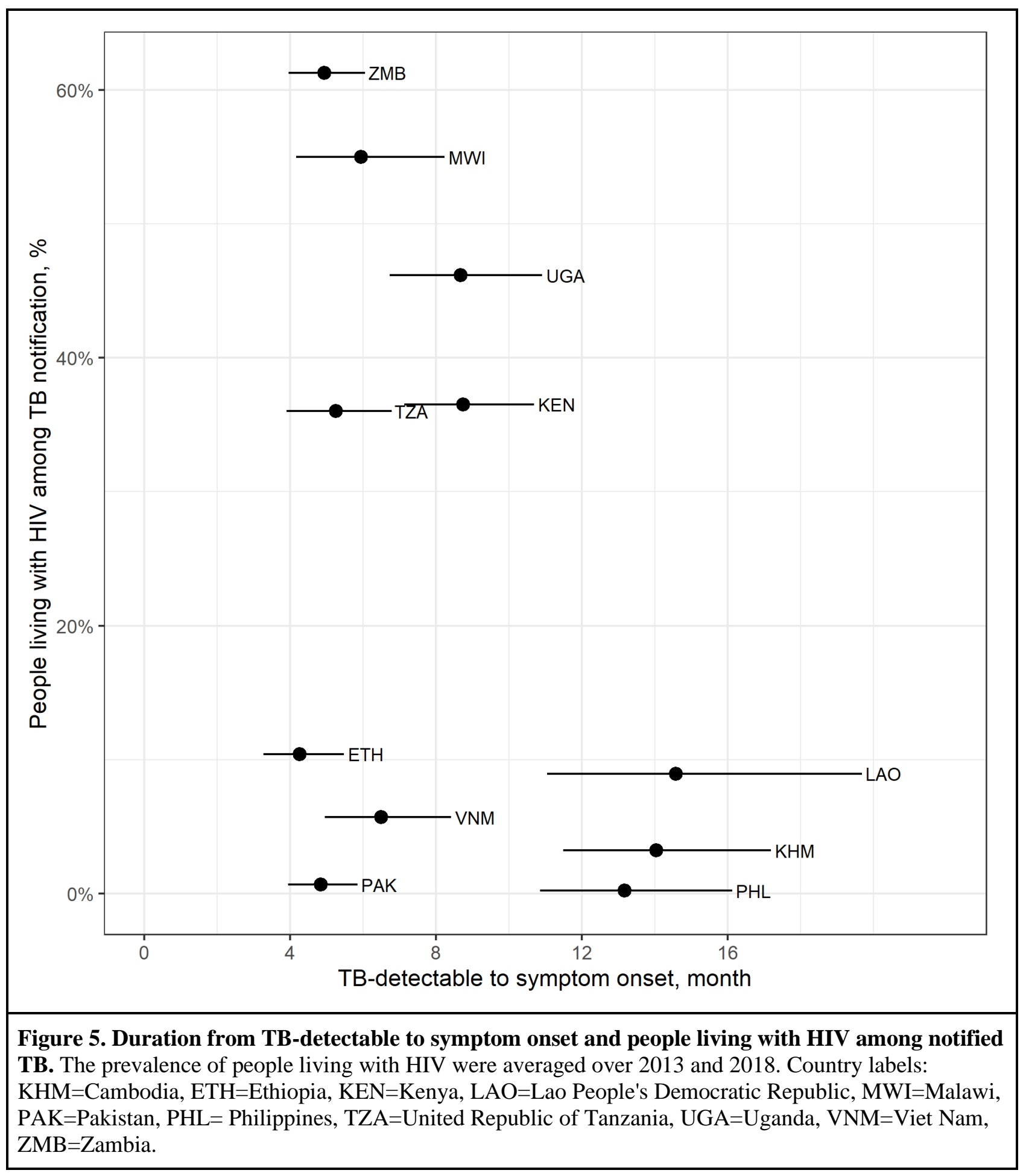




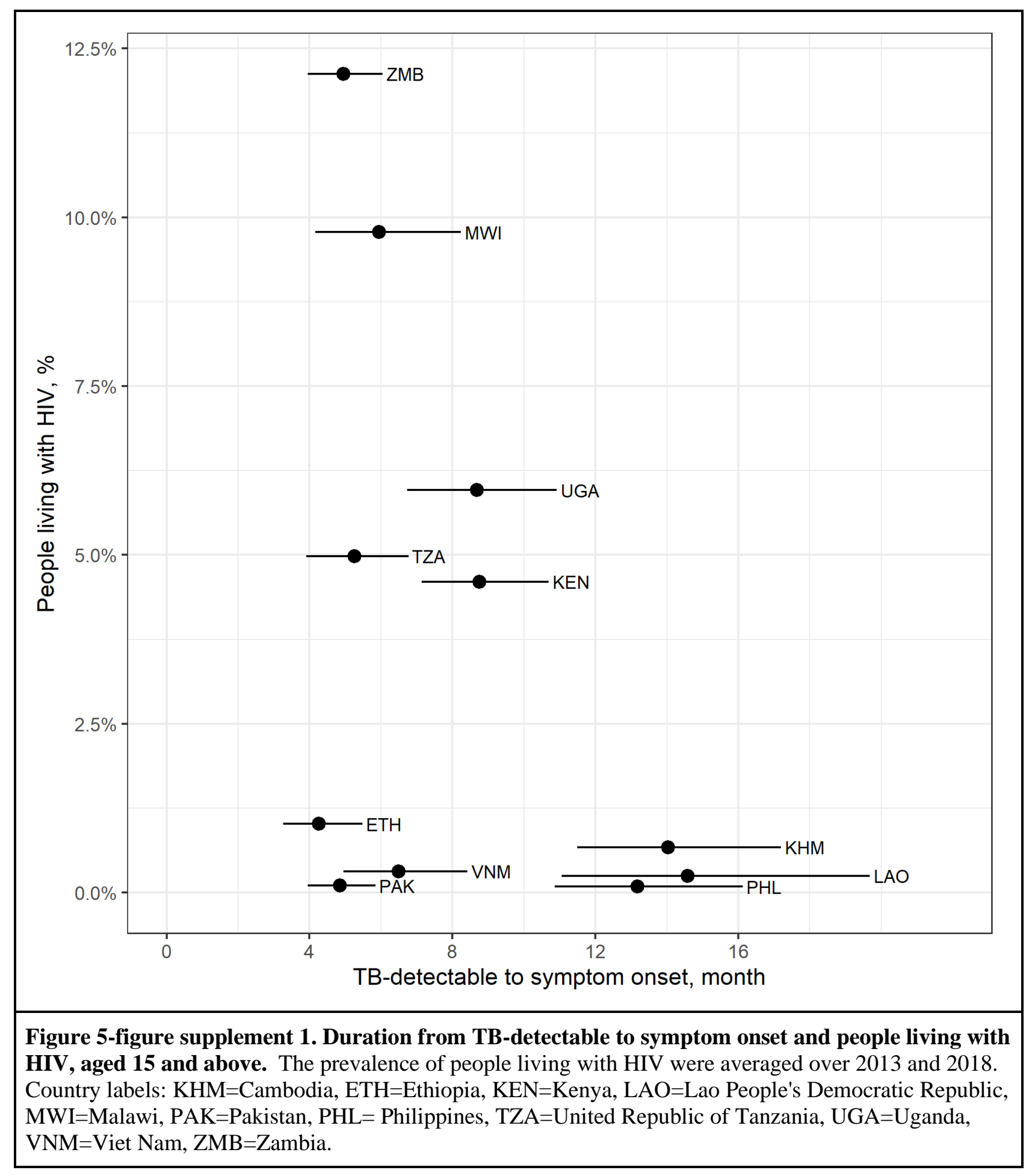


medRxiv preprint doi: https://doi.org/10.1101/2021.03.17.21253823; this version posted April 4, 2021. The copyright holder for this preprint (which was not certified by peer review) is the author/funder, who has granted medRxiv a license to display the preprint in perpetuity.

It is made available under a CC-BY 4.0 International license.

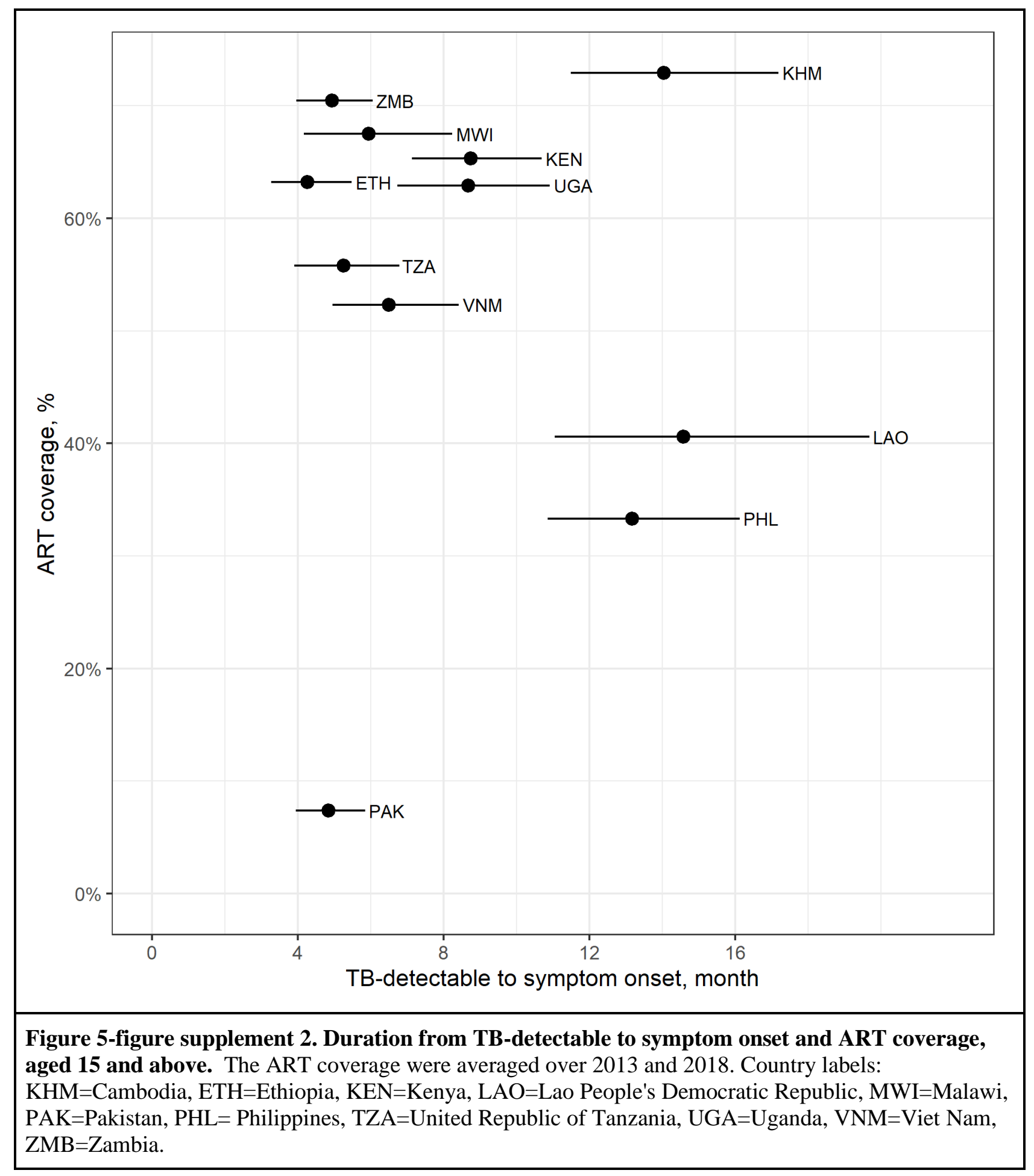




\section{Tables}

Table 1. Epidemiological indices and data

\begin{tabular}{|c|c|c|c|c|c|c|c|c|c|c|c|}
\hline & Cambodia & Ethiopia & Kenya & Lao PDR & Malawi & Pakistan & Philippines & Uganda & Tanzania & Viet Nam & Zambia \\
\hline $\begin{array}{l}\text { Population aged } 15 \text { and above, } \\
\text { 2019, million }\end{array}$ & 11.4 & 66.9 & 32 & 4.9 & 10.5 & 140.6 & 75.2 & 23.7 & 32.6 & 74.1 & 9.9 \\
\hline \multicolumn{12}{|l|}{ Prevalence survey } \\
\hline $\begin{array}{l}\text { Survey year } \\
\text { Prevalence in the survey year, per }\end{array}$ & 2011 & 2010-2011 & 2016 & 2010-2011 & 2013 & 2010-2011 & 2016 & 2014-2015 & 2012 & 2017-2018 & 2013-2014 \\
\hline $100,000^{*}$ & $839(748-933)$ & $236(193-281)$ & $478(425-532)$ & $604(528-683)$ & $418(348-491)$ & $325(291-360)$ & $998(908-1090)$ & $395(335-456)$ & $305(258-355)$ & $358(311-406)$ & $575(508-644)$ \\
\hline \multicolumn{12}{|l|}{ WHO data/estimates } \\
\hline 100,000 & $247(244-250)$ & $150(149-150)$ & $238(236-240)$ & $138(135-142)$ & $146(144-148)$ & $201(200-202)$ & $488(486-489)$ & $238(236-240)$ & $212(210-213)$ & $136(135-137)$ & $340(336-343)$ \\
\hline Case-detection ratio & $57(40.0-88)$ & $69(51.0-98)$ & $63(43.0-100)$ & $57(40.0-89)$ & $56(35.0-110)$ & $64(48.0-90)$ & $63(40.0-110)$ & $65(43.0-110)$ & $53(30.0-110)$ & $57(40.0-90)$ & $58(41.0-90)$ \\
\hline Incidence rate, 2009 , per 100,000 & $387(220-546)$ & $208(133-283)$ & $385(194-572)$ & $206(120-288)$ & $218(85-361)$ & $351(225-478)$ & $705(310-1102)$ & $304(135-473)$ & $356(98-617)$ & $219(127-312)$ & $534(302-766)$ \\
\hline \multicolumn{12}{|c|}{ Model estimates: All TB regardless of symptomatic or not } \\
\hline Duration by P:N ratio, month** & $\begin{array}{l}28.9(25.8- \\
32.3)\end{array}$ & $10.2(8.4-12.3)$ & $\begin{array}{l}25.1(22.5- \\
28.0)\end{array}$ & $\begin{array}{l}109.4(95.1- \\
125.6)\end{array}$ & $\begin{array}{l}29.7(25.1- \\
34.9)\end{array}$ & $\begin{array}{l}17.8(15.9- \\
19.9)\end{array}$ & $33.3(30.5-36.4)$ & $24.5(21.0-28.5)$ & $20.8(17.7-24.2)$ & $\begin{array}{l}33.0(28.6- \\
37.3)\end{array}$ & $\begin{array}{l}16.0(14.2- \\
18.0)\end{array}$ \\
\hline $\begin{array}{l}\text { Time to notification (Total } \\
\text { duration), month }\end{array}$ & $\begin{array}{l}22.0(18.9- \\
25.8)\end{array}$ & $9.0(7.5-10.8)$ & $\begin{array}{l}18.3(16.1- \\
21.0)\end{array}$ & $36.1(29.9-45.3)$ & $\begin{array}{l}21.8(18.4- \\
25.9)\end{array}$ & $\begin{array}{l}13.1(11.5- \\
14.8)\end{array}$ & $22.3(19.6-25.6)$ & $19.1(16.4-22.2)$ & $16.2(14.0-18.8)$ & $\begin{array}{l}20.7(17.8- \\
24.5)\end{array}$ & $\begin{array}{l}13.4(11.8- \\
15.2)\end{array}$ \\
\hline Case-detection ratio*** & $\begin{array}{l}67 \%(56 \%- \\
79 \%)\end{array}$ & $\begin{array}{l}87 \%(80 \%- \\
94 \%)\end{array}$ & $\begin{array}{l}69 \%(60 \%- \\
79 \%)\end{array}$ & $24 \%(19 \%-31 \%)$ & $\begin{array}{l}63 \%(53 \%- \\
74 \%)\end{array}$ & $\begin{array}{l}76 \%(68 \%- \\
84 \%)\end{array}$ & $53 \%(46 \%-62 \%)$ & $63 \%(53 \%-72 \%)$ & $68 \%(59 \%-77 \%)$ & $\begin{array}{l}59 \%(50 \%- \\
70 \%)\end{array}$ & $\begin{array}{l}79 \%(71 \%- \\
88 \%)\end{array}$ \\
\hline Incidence rate, per 100,000 & $342(285-403)$ & $168(156-183)$ & $360(312-414)$ & $595(449-743)$ & $222(187-265)$ & $287(259-319)$ & $914(782-1,055)$ & $354(305-412)$ & $307(271-352)$ & $230(194-272)$ & $426(382-474)$ \\
\hline \multicolumn{12}{|c|}{ Model estimates: All symptomatic TB } \\
\hline Duration by P:N ratio, month & $8.7(7.1-10.5)$ & $5.3(4.0-6.7)$ & $\begin{array}{l}11.8(9.9- \\
13.8)\end{array}$ & $53.4(43.6-64.1)$ & $\begin{array}{l}20.6(16.7- \\
24.9)\end{array}$ & $10.9(9.4-12.4)$ & $10.9(9.2-12.7)$ & $11.9(9.4-14.6)$ & $13.3(10.7-16.0)$ & $\begin{array}{l}21.9(18.6- \\
25.6)\end{array}$ & $9.7(8.2-11.3)$ \\
\hline Time to care-seeking start, month & $1.2(0.6-1.9)$ & N.A. & $5.6(4.6-6.8)$ & N.A. & $\begin{array}{l}6.6(4.8-8.6) \\
15.8(13.2-\end{array}$ & N.A. & $4.2(3.3-5.2)$ & $4.2(3.0-5.6)$ & $6.3(4.9-7.8)$ & $\begin{array}{l}\text { N.A. } \\
14.2(12.1-\end{array}$ & $4.1(3.3-5.1)$ \\
\hline Time to notification, month & $8.0(6.7-9.6)$ & $4.8(3.7-6.0)$ & $9.5(8.2-11.1)$ & $21.6(18.0-26.8)$ & 19.0) & $8.2(7.2-9.4)$ & $9.2(7.9-10.6)$ & $10.4(8.5-12.5)$ & $10.9(9.1-13.0)$ & $16.8)$ & $8.5(7.3-9.8)$ \\
\hline Case-detection ratio & $\begin{array}{l}83 \%(77 \%- \\
89 \%)\end{array}$ & $\begin{array}{l}92 \%(87 \%- \\
96 \%)\end{array}$ & $\begin{array}{l}80 \%(73 \%- \\
86 \%)\end{array}$ & $36 \%(29 \%-44 \%)$ & $\begin{array}{l}69 \%(59 \%- \\
79 \%)\end{array}$ & $\begin{array}{l}82 \%(76 \%- \\
88 \%)\end{array}$ & $75 \%(69 \%-81 \%)$ & $75 \%(67 \%-82 \%)$ & $75 \%(67 \%-82 \%)$ & $\begin{array}{l}66 \%(57 \%- \\
75 \%)\end{array}$ & $\begin{array}{l}85 \%(78 \%- \\
91 \%)\end{array}$ \\
\hline Incidence rate, per 100,000 & $270(252-292)$ & $160(154-169)$ & $309(286-338)$ & $396(315-482)$ & $203(177-235)$ & $265(247-285)$ & $643(593-700)$ & $296(269-329)$ & $277(252-309)$ & $206(181-235)$ & $397(369-429)$ \\
\hline \multicolumn{12}{|l|}{ Other estimates / metrics } \\
\hline Annual decline rate, $\%$ per year & $\begin{array}{l}4.7 \%(4.4 \%- \\
5.0 \%)\end{array}$ & $\begin{array}{l}7.3 \%(7.1 \%- \\
7.5 \%)\end{array}$ & $\begin{array}{l}1.5 \%(1.3 \%- \\
1.6 \%)\end{array}$ & $\begin{array}{l}-8.0 \%(-8.5 \%-- \\
7.5 \%)\end{array}$ & $\begin{array}{l}2.9 \%(2.6 \%- \\
3.2 \%)\end{array}$ & $\begin{array}{l}1.6 \%(1.5 \%- \\
1.7 \%)\end{array}$ & $\begin{array}{l}-8.3 \%(-8.4 \%-- \\
8.2 \%)\end{array}$ & $\begin{array}{l}-2.4 \%(-2.7 \%-- \\
2.2 \%)\end{array}$ & $\begin{array}{l}-1.3 \%(-1.5 \%-- \\
1.1 \%)\end{array}$ & $\begin{array}{l}1.0 \%(0.7 \%- \\
1.4 \%)\end{array}$ & $\begin{array}{l}4.9 \%(4.7 \%- \\
5.1 \%)\end{array}$ \\
\hline $\begin{array}{l}\text { Asymptomatic phase over total } \\
\text { duration, } \%\end{array}$ & $\begin{array}{l}64 \%(58 \%- \\
69 \%)\end{array}$ & $\begin{array}{l}47 \%(39 \%- \\
56 \%)\end{array}$ & $\begin{array}{l}48 \%(42 \%- \\
53 \%)\end{array}$ & $40 \%(35 \%-45 \%)$ & $\begin{array}{l}27 \%(21 \%- \\
35 \%)\end{array}$ & $\begin{array}{l}37 \%(32 \%- \\
42 \%)\end{array}$ & $59 \%(53 \%-65 \%)$ & $45 \%(38 \%-53 \%)$ & $32 \%(26 \%-40 \%)$ & $\begin{array}{l}31 \%(26 \%- \\
37 \%)\end{array}$ & $\begin{array}{l}37 \%(31 \%- \\
43 \%)\end{array}$ \\
\hline $\begin{array}{l}\text { Symptomatic TB without care- } \\
\text { seeking, } \%\end{array}$ & $\begin{array}{l}15 \%(9 \%- \\
23 \%)\end{array}$ & N.A. & $\begin{array}{l}59 \%(51 \%- \\
67 \%)\end{array}$ & N.A. & $\begin{array}{l}42 \%(33 \%- \\
51 \%)\end{array}$ & N.A. & $46 \%(38 \%-54 \%)$ & $41 \%(31 \%-50 \%)$ & $57 \%(48 \%-67 \%)$ & N.A. & $\begin{array}{l}48 \%(40 \%- \\
56 \%)\end{array}$ \\
\hline Self-cure before case-detection & $\begin{array}{l}32 \%(20 \%- \\
42 \%)\end{array}$ & $\begin{array}{l}14 \%(8 \%- \\
21 \%)\end{array}$ & $\begin{array}{l}27 \%(16 \%- \\
36 \%)\end{array}$ & $50 \%(35 \%-61 \%)$ & $\begin{array}{l}30 \%(19 \%- \\
41 \%)\end{array}$ & $\begin{array}{l}20 \%(12 \%- \\
28 \%)\end{array}$ & $32 \%(20 \%-42 \%)$ & $27 \%(17 \%-37 \%)$ & $23 \%(14 \%-33 \%)$ & $\begin{array}{l}30 \%(19 \%- \\
41 \%)\end{array}$ & $\begin{array}{l}20 \%(12 \%- \\
28 \%)\end{array}$ \\
\hline Deaths before case-detection & $7 \%(6 \%-9 \%)$ & $3 \%(2 \%-4 \%)$ & $6 \%(5 \%-7 \%)$ & $19 \%(15 \%-26 \%)$ & $\begin{array}{l}10 \%(8 \%- \\
12 \%)\end{array}$ & $6 \%(5 \%-7 \%)$ & $6 \%(5 \%-7 \%)$ & $8 \%(6 \%-10 \%)$ & $8 \%(6 \%-9 \%)$ & $\begin{array}{l}12 \%(10 \%- \\
14 \%)\end{array}$ & $5 \%(4 \%-6 \%)$ \\
\hline
\end{tabular}

* values are crude rates or proportions with $95 \%$ Binomial confidence intervals, while the model estimates are mean estimators with $95 \%$ credible intervals

** P:N ratios use prevalence from the model estimates for 2019 and notified cases from WHO 2019 TB notification data 
*** Case-detection ratio is defined as the ratio of notified cases and the estimated incident cases in

percentage

Table 1. table supplement 1. Extracted information from the national TB prevalence surveys

\begin{tabular}{|c|c|c|c|c|c|c|}
\hline Country & Survey year & $\begin{array}{c}\text { Reported prevalence estimates, } \\
\text { per } 100000 \text { with } 95 \% \text { confidence } \\
\text { interval }\end{array}$ & $\begin{array}{l}\text { Cases with TB suggestive } \\
\text { symptoms }\end{array}$ & Symptoms & $\begin{array}{l}\quad \text { Raw counts in the analysis } \\
\text { (Asymptomatic }+ \text { Symptomatic) / subjects }\end{array}$ & $\begin{array}{l}\text { Care-seeking behaviour } \\
\text { reported }\end{array}$ \\
\hline Cambodia & 2011 & $\begin{array}{l}\text { Overall: } 831(707-977) \\
\text { Female: } 609(486-763) \\
\text { Male: } 1,097(895-1343)\end{array}$ & $\begin{array}{l}23 \% \text { of Smr- } \\
44 \% \text { of Smr+ }\end{array}$ & $\begin{array}{c}\text { Cough } \geq 2 \text { weeks and } \\
\text { haemoptysis }\end{array}$ & $\begin{array}{l}\text { Total: }(221+93) / 37,417 \\
\text { Female: }(89+37) / 20,410 \\
\text { Male: }(132+56) / 17,007\end{array}$ & $\begin{array}{l}\text { Survey participants with } \\
\text { screening symptoms } \\
\text { Female: } 92 \% \\
\text { Male: } 84 \%\end{array}$ \\
\hline Ethiopia & 2010-2011 & $\begin{array}{l}\text { Overall: } 277(208-347) \\
\text { Female: } 246(176-315) \\
\text { Male: } 304(219-388)\end{array}$ & $\begin{array}{l}48 \% \text { of Smr- } \\
57 \% \text { of Smr+ }\end{array}$ & Cough $\geq 2$ weeks & $\begin{array}{c}\text { Total: }(53+57) / 46,697 \\
\text { Female: }(26+28) / 24,878 \\
\text { Male: }(27+29) / 21,819\end{array}$ & \\
\hline Kenya & 2016 & $\begin{array}{l}\text { Overall: } 558(455-662) \\
\text { Female: } 359(258-460) \\
\text { Male: } 809(656-962)\end{array}$ & Exact counts & Cough $\geq 2$ weeks & $\begin{array}{c}\text { Total: }(161+140) / 62,988 \\
\text { Female: }(62+52) / 36,974 \\
\text { Male: }(99+88) / 26,014\end{array}$ & $\begin{array}{c}\text { Survey TB cases with } \\
\text { symptoms } \\
\text { Female: } 21(40 \%) \\
\text { Male: } 32(36 \%)\end{array}$ \\
\hline Lao PDR & 2010-2011 & $\begin{array}{l}\text { Overall: } 595(457-733) \\
\text { Female: } 366(254-477) \\
\text { Male: } 855(646-1064)\end{array}$ & $\begin{array}{l}36 \% \text { of Smr- } \\
66 \% \text { of Smr+ }\end{array}$ & $\begin{array}{l}\text { Cough } \geq 2 \text { weeks or } \\
\text { haemoptysis }\end{array}$ & $\begin{array}{c}\text { Total: }(119+118) / 39,212 \\
\text { Female: }(41+39) / 21,474 \\
\text { Male: }(78+79) / 17,738\end{array}$ & \\
\hline Malawi & 2013 & $\begin{array}{l}\text { Total: } 452(312-593) \\
\text { Female: } 374(246-501) \\
\text { Male: } 546(335-757)\end{array}$ & $\begin{array}{l}73 \% \text { of Smr- } \\
66 \% \text { of Smr+ }\end{array}$ & Cough $\geq 2$ weeks & $\begin{array}{c}\text { Total: }(40+92) / 31,579 \\
\text { Female: }(21+48) / 18,490 \\
\text { Male: }(19+44) / 13,089\end{array}$ & $\begin{array}{c}\text { Survey TB cases with } \\
\text { symptoms } \\
\text { Smr-: } 51 \% \\
\text { Smr+: } 61 \%\end{array}$ \\
\hline Pakistan & 2010-2011 & $\begin{array}{c}\text { Total: } 398(333-463) \\
\text { Female: } 320(253-388) \\
\text { Male: } 484(392-577)\end{array}$ & $61 \%$ of all $\mathrm{BC}$ & Cough $\geq 2$ weeks & $\begin{array}{l}\text { Total: }(132+208) / 104,631 \\
\text { Female: }(62+98) / 60,382 \\
\text { Male: }(70+110) / 44,249\end{array}$ & \\
\hline Philippines & 2016 & $\begin{array}{l}\text { Overall: } 1,159(1,016-1,301) \\
\text { Female: } 627(516-739) \\
\text { Male: } 1,713(1,482-1,943)\end{array}$ & $\begin{array}{l}21 \% \text { of Smr- } \\
51 \% \text { of Smr+ }\end{array}$ & $\begin{array}{c}\text { Cough } \geq 2 \text { weeks and } \\
\text { haemoptysis }\end{array}$ & $\begin{array}{l}\text { Total: }(316+150) / 46,689 \\
\text { Female: }(99+45) / 25,796 \\
\text { Male: }(217+105) / 20,893\end{array}$ & $\begin{array}{l}\text { Survey TB cases with } \\
\text { symptoms } \\
\text { Total: } 71 \%\end{array}$ \\
\hline Uganda & 2014-2015 & $\begin{array}{l}\text { Total: } 401(292-509) \\
\text { Female: } 178(109-248) \\
\text { Male: } 734(554-914)\end{array}$ & $\begin{array}{l}46 \% \text { of Smr- } \\
52 \% \text { of Smr+ }\end{array}$ & Cough $\geq 2$ weeks & $\begin{array}{c}\text { Total: }(83+77) / 40,539 \\
\text { Female: }(21+19) / 23,393 \\
\text { Male: }(62+58) / 17,146\end{array}$ & $\begin{array}{l}\text { Survey participants with } \\
\text { screening symptoms } \\
\text { Female: } 67 \% \\
\text { Male: } 54 \%\end{array}$ \\
\hline Tanzania & 2012 & $\begin{array}{l}\text { Total: } 293(228-358) \\
\text { Female: } 204(137-272) \\
\text { Male: } 410(315-505)\end{array}$ & $63 \%$ of all $\mathrm{BC}$ & $\begin{array}{c}\text { Cough } \geq 2 \text { weeks, } \\
\text { haemoptysis, fever } \geq 2 \\
\text { weeks, weight loss and } \\
\text { excessive night sweats }\end{array}$ & $\begin{array}{c}\text { Total: }(56+98) / 50,436 \\
\text { Female: }(23+41) / 29,701 \\
\text { Male: }(33+57) / 20,735\end{array}$ & $\begin{array}{l}\text { Survey participants with } \\
\text { screening symptoms } \\
\text { Female: } 39.1 \% \\
\text { Male: } 37.7 \%\end{array}$ \\
\hline Vietnam & 2017-2018 & $\begin{array}{l}\text { Total: } 322(260-399) \\
\text { Female: } 133(89-198) \\
\text { Male: } 522(420-648)\end{array}$ & $67 \%$ of all $\mathrm{BC}$ & Cough $\geq 2$ weeks & $\begin{array}{l}\text { Total: }(73+148) / 61,763 \\
\text { Female: }(15+31) / 34,613 \\
\text { Male: }(58+117) / 27,150\end{array}$ & \\
\hline Zambia & 2013-2014 & $\begin{array}{l}\text { Total: } 638(502-774) \\
\text { Female: } 487(353-621) \\
\text { Male: } 833(641-1,024)\end{array}$ & $61 \%$ of all BC & Cough $\geq 2$ weeks & $\begin{array}{c}\text { Total: }(105+160) / 46,099 \\
\text { Female: }(45+68) / 26,642 \\
\text { Male: }(60+92) / 19,457\end{array}$ & $\begin{array}{l}\text { Survey TB cases with } \\
\text { symptoms } \\
\text { Total: } 50 \%\end{array}$ \\
\hline
\end{tabular}


medRxiv preprint doi: https://doi.org/10.1101/2021.03.17.21253823; this version posted April 4, 2021. The copyright holder for this preprint
(which was not certified by peer review) is the authorffunder, who has granted medRxiv a license to display the preprint in perpetuity.
It is made available under a CC-BY 4.0 International license.

Table 2. Asymptomatic, symptomatic and total TB duration by sex, age and HIV status

\begin{tabular}{|c|c|c|c|c|c|c|c|c|}
\hline & & & \multirow{2}{*}{$\begin{array}{l}\text { Asymptomatic } \\
\text { duration, month }\end{array}$} & \multicolumn{3}{|c|}{ Symptom onset rate after TB activation, per year } & \multirow{2}{*}{$\begin{array}{l}\text { Symptomatic } \\
\text { duration, month }\end{array}$} & \multirow{2}{*}{$\begin{array}{l}\text { Total } \\
\text { duration, month }\end{array}$} \\
\hline & & & & Crude rate & Crude RR & Adjusted RR & & \\
\hline \multirow[t]{11}{*}{ Kenya } & Overall & & $8.3(6.8-10.1)$ & $1.25(1.05-1.50)$ & & & $8.4(7.1-9.7)$ & $16.7(14.5-19.1)$ \\
\hline & \multirow{2}{*}{ Sex } & Female & $8.1(6.2-10.3)$ & $1.30(1.01-1.69)$ & reference & reference & $7.2(5.8-8.8)$ & $15.4(13.0-18.1)$ \\
\hline & & Male & $9.0(7.2-11.2)$ & $1.14(0.93-1.40)$ & $0.89(0.63-1.20)$ & $0.68(0.50-0.89)$ & $9.7(8.2-11.5)$ & $18.8(16.1-21.8)$ \\
\hline & \multirow{6}{*}{ Age } & {$[15,25)$} & $9.5(6.6-13.0)$ & $1.11(0.76-1.60)$ & reference & reference & $10.4(7.9-13.2)$ & $20.0(16.1-24.4)$ \\
\hline & & {$[25,35)$} & $8.6(6.3-11.4)$ & $1.23(0.90-1.66)$ & $1.13(0.75-1.67)$ & $1.20(0.77-1.69)$ & $9.4(7.5-11.5)$ & $18.0(15.0-21.6)$ \\
\hline & & {$[35,45)$} & $7.1(5.0-9.7)$ & $1.55(1.08-2.22)$ & $1.43(0.87-2.17)$ & $1.72(1.10-2.54)$ & $7.7(5.9-9.7)$ & $14.7(11.9-18.1)$ \\
\hline & & {$[45,55)$} & $7.4(4.8-10.7)$ & $1.49(0.94-2.31)$ & $1.39(0.80-2.43)$ & $1.82(0.95-3.17)$ & $8.3(6.0-11.1)$ & $15.7(12.4-19.7)$ \\
\hline & & {$[55,65)$} & $9.6(6.1-13.7)$ & $1.10(0.70-1.74)$ & $1.02(0.55-1.72)$ & $1.23(0.68-2.06)$ & $5.2(3.1-8.3)$ & $14.8(10.9-19.4)$ \\
\hline & & {$[65$, Inf $)$} & $7.1(4.6-10.2)$ & $1.52(0.97-2.35)$ & $1.43(0.80-2.55)$ & $1.42(0.89-2.34)$ & $5.3(3.4-7.7)$ & $12.4(9.4-16.0)$ \\
\hline & \multirow[t]{2}{*}{ HIV } & $\begin{array}{l}\text { Non- } \\
\text { HIV }\end{array}$ & $9.8(7.9-12.2)$ & $1.03(0.85-1.25)$ & reference & reference & $9.9(8.5-11.7)$ & $19.7(17.1-23.0)$ \\
\hline & & PLHIV & $3.8(2.4-5.6)$ & $3.09(1.96-4.80)$ & $2.88(1.82-4.54)$ & $2.45(1.45-3.68)$ & $4.0(2.5-5.7)$ & $7.8(5.8-10.2)$ \\
\hline \multirow[t]{7}{*}{ Blantyre } & \multicolumn{2}{|l|}{ Overall } & $3.8(2.3-5.8)$ & $3.10(1.86-4.98)$ & & & $3.7(2.3-5.4)$ & $7.5(5.4-10.1)$ \\
\hline & \multirow{2}{*}{ Sex } & Female & $3.5(1.3-6.2)$ & $3.90(1.73-8.83)$ & reference & reference & $3.1(1.3-5.5)$ & $6.6(3.5-10.2)$ \\
\hline & & Male & $4.9(2.6-7.9)$ & $2.46(1.34-4.48)$ & $0.82(0.29-1.82)$ & $0.81(0.30-1.71)$ & $5.0(2.9-7.7)$ & $9.9(6.7-13.8)$ \\
\hline & \multirow{2}{*}{ Age } & {$[15,50)$} & $4.0(2.3-6.2)$ & $3.00(1.74-5.03)$ & reference & reference & $3.7(2.1-5.6)$ & $7.7(5.3-10.3)$ \\
\hline & & {$[50, \operatorname{Inf})$} & $3.5(1.1-7.1)$ & $4.17(1.46-10.84)$ & $1.53(0.45-3.94)$ & $1.41(0.47-4.16)$ & $4.6(1.9-8.1)$ & $8.1(4.3-12.5)$ \\
\hline & \multirow{2}{*}{ HIV } & $\begin{array}{l}\text { Non- } \\
\text { HIV }\end{array}$ & $8.5(5.0-12.7)$ & $1.29(0.76-2.16)$ & reference & reference & $7.1(4.3-10.8)$ & $15.6(11.3-20.8)$ \\
\hline & & PLHIV & $1.3(0.3-3.0)$ & $\begin{array}{l}12.79(3.77- \\
41.16)\end{array}$ & $5.33(1.90-11.92)$ & $4.81(1.65-12.82)$ & $2.4(1.0-4.1)$ & $3.7(1.9-6.0)$ \\
\hline
\end{tabular}

RR: risk ratio, PLHIV: people living with HIV 
medRxiv preprint doi: htpps://doi.org/10.1101/2021.03.17.21253823; this version posted April 4, 2021. The copyright holder for this preprint
(which was not certified by peer revieus) is the authorffunder, who has granted medR Rxiv alicense to display the preprint in perpetuity.
It is made available under a CC-BY 4.0 International license.

Table 3. TB incidence, case detection ratio, and symptomatic duration by HIV status: Kenya and Blantyre, Malawi

\begin{tabular}{|c|c|c|c|c|c|c|}
\hline \multirow[b]{2}{*}{ HIV status } & \multicolumn{3}{|c|}{ Kenya } & \multicolumn{3}{|c|}{ Blantyre } \\
\hline & $\frac{\text { Non-HIV }}{\mu}$ & \multicolumn{2}{|c|}{ PLHIV } & $\frac{\text { Non-HIV }}{\mu}$ & \multicolumn{2}{|c|}{ PLHIV } \\
\hline excess mortality for symptomatic TB & \multicolumn{2}{|c|}{$\begin{array}{l}\text { Smear-: } 50 \% / 10 \text { years } \\
\text { Smeart: } 70 \% / 10 \text { years }\end{array}$} & $5 \%$ per month & \multicolumn{2}{|c|}{$\begin{array}{l}\text { Smear-: 50\% / } 10 \text { years } \\
\text { Smear+: } 70 \% / 10 \text { years }\end{array}$} & $5 \%$ per month \\
\hline \multicolumn{7}{|c|}{ All TB regardless of symptomatic or not } \\
\hline Time to symptom onset, month & $10.35(8.41-12.84)$ & $3.81(2.34-5.51)$ & $3.22(1.99-4.75)$ & $8.79(5.14-13.18)$ & $1.32(0.31-3.04)$ & $1.15(0.25-2.64)$ \\
\hline Time to notification, month & $20.90(18.01-24.46)$ & $7.79(5.78-9.99)$ & $6.49(4.94-8.11)$ & $16.27(11.59-21.53)$ & $3.76(1.81-6.07)$ & $3.26(1.76-5.03)$ \\
\hline \multicolumn{7}{|l|}{ All symptomatic TB } \\
\hline Time to notification, month & $10.56(8.86-12.48)$ & $3.99(2.52-5.56)$ & $3.27(2.16-4.40)$ & $7.47(4.53-11.05)$ & $2.44(1.00-4.25)$ & $2.11(0.95-3.49)$ \\
\hline Case-detection ratio & $83 \%(75 \%-91 \%)$ & $90 \%(85 \%-95 \%)$ & $76 \%(67 \%-84 \%)$ & $88 \%(79 \%-95 \%)$ & $95 \%(90 \%-98 \%)$ & $85 \%(75 \%-94 \%)$ \\
\hline Incidence rate, per 100,000 & $218(198-240)$ & $1,882(1,791-2,003)$ & $2,260(2,025-2,542)$ & $136(121-155)$ & $1,712(1,604-1,831)$ & $1,921(1,721-2,177)$ \\
\hline
\end{tabular}

Incidence rate, per 100,000

$-1,882(1,791-2,003)-2,260(2,025-2542)+136(121-155)$

HIV-related mortality: AIDS-related deaths / PLHIV for aged 15 and above from the UNAIDS data

$5 \%$ per month (0.61 per year): an extreme case for gold miner in pre-ART era used by Vynnycky et al. [26] 


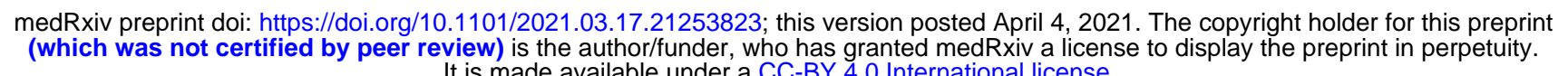

Table 4 Sensitivity analysis on the asymptomatic period estimates

\begin{tabular}{|c|c|c|c|c|c|}
\hline Scenario & M0 & M1 & M2 & M3 & M4 \\
\hline \multicolumn{6}{|l|}{ Assumptions } \\
\hline Background mortality & 0 & \multirow{2}{*}{\multicolumn{3}{|c|}{$\mu$}} & \\
\hline Excess mortality for asymptomatic TB & & & & & $50 \% / 10$ years \\
\hline Excess mortality for symptomatic TB & \multicolumn{2}{|c|}{0} & $50 \% / 10$ years & \multicolumn{2}{|c|}{$\begin{array}{l}\text { Average over smear status } \\
\text { Smear-: } 50 \% \text { / } 10 \text { years } \\
\text { Smear+: } 70 \% \text { / } 10 \text { years }\end{array}$} \\
\hline \multicolumn{6}{|l|}{ Duration of asymptomatic TB } \\
\hline Cambodia & $\begin{array}{c}14.95(12.22- \\
18.52)\end{array}$ & $\begin{array}{c}14.41(11.89- \\
17.69)\end{array}$ & $\begin{array}{c}14.37(11.83- \\
17.58)\end{array}$ & $\begin{array}{c}13.91(11.51- \\
16.96)\end{array}$ & $\begin{array}{c}13.60(11.23- \\
16.49)\end{array}$ \\
\hline Ethiopia & $4.40(3.39-5.58)$ & $4.40(3.35-5.62)$ & $4.36(3.31-5.55)$ & $4.28(3.29-5.40)$ & $4.24(3.24-5.43)$ \\
\hline Kenya & $9.31(7.61-11.33)$ & $9.22(7.53-11.33)$ & $9.08(7.42-11.08)$ & $8.76(7.10-10.73)$ & $8.63(7.11-10.51)$ \\
\hline Lao PDR & $\begin{array}{c}17.13(12.86- \\
24.17)\end{array}$ & $\begin{array}{c}16.22(12.19- \\
22.38)\end{array}$ & $\begin{array}{l}15.98(12.05- \\
21.95)\end{array}$ & $\begin{array}{c}14.52(10.99- \\
19.54)\end{array}$ & $\begin{array}{c}14.11(10.76- \\
18.78)\end{array}$ \\
\hline Malawi & $6.64(4.67-9.18)$ & $6.44(4.59-8.86)$ & $6.33(4.45-8.72)$ & $6.00(4.12-8.24)$ & $5.89(4.14-8.10)$ \\
\hline Pakistan & $\begin{array}{c}5.16(4.18-6.25) \\
13.99(11.64-\end{array}$ & $\begin{array}{c}5.09(4.16-6.14) \\
13.65(11.32-\end{array}$ & $\begin{array}{c}5.00(4.09-6.11) \\
13.44(11.18-\end{array}$ & $\begin{array}{c}4.86(3.97-5.86) \\
13.13(10.94-\end{array}$ & $\begin{array}{c}4.82(3.94-5.80) \\
12.89(10.71-\end{array}$ \\
\hline Philippines & $17.01)$ & 16.49) & $16.42)$ & $15.96)$ & $15.53)$ \\
\hline Tanzania & $5.73(4.23-7.60)$ & $5.59(4.18-7.19)$ & $5.52(4.16-7.09)$ & $5.29(3.94-6.87)$ & $5.23(3.90-6.84)$ \\
\hline Uganda & $9.42(7.24-11.95)$ & $9.26(7.14-11.68)$ & $9.11(7.17-11.43)$ & $8.72(6.83-11.03)$ & $8.55(6.66-10.75)$ \\
\hline Vietnam & $7.38(5.47-9.68)$ & $7.20(5.34-9.52)$ & $6.99(5.29-9.18)$ & $6.50(4.98-8.36)$ & $6.47(4.89-8.35)$ \\
\hline Zambia & $5.23(4.18-6.40)$ & $5.18(4.12-6.38)$ & $5.10(4.10-6.32)$ & $4.98(3.98-6.12)$ & $4.93(3.98-6.04)$ \\
\hline
\end{tabular}




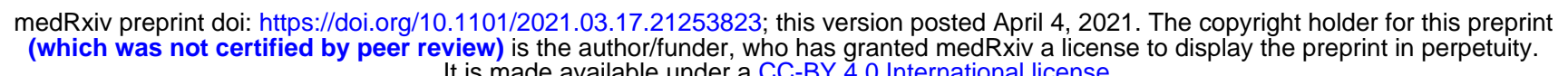

Table 4-table supplement 1 Sensitivity analysis: assumptions on untreated TB mortality rates

\begin{tabular}{|c|c|c|c|c|c|}
\hline Scenario & M0 & M1 & M2 & M3 & M4 \\
\hline \multicolumn{6}{|l|}{ Assumptions } \\
\hline Background mortality & 0 & & & $\mu$ & \\
\hline Excess mortality for asymptomatic TB & & & 0 & & $50 \% / 10$ years \\
\hline Excess mortality for symptomatic $\mathrm{TB}$ & & 0 & $50 \% / 10$ years & \multicolumn{2}{|c|}{$\begin{array}{l}\text { Average over smear status } \\
\text { Smear-: } 50 \% / 10 \text { years } \\
\text { Smear+: } 70 \% / 10 \text { years }\end{array}$} \\
\hline \multicolumn{6}{|l|}{ Duration of asymptomatic TB } \\
\hline Cambodia & $14.95(12.22-18.52)$ & $14.41(11.89-17.69)$ & $14.37(11.83-17.58)$ & $13.91(11.51-16.96)$ & $13.60(11.23-16.49)$ \\
\hline Ethiopia & $4.40(3.39-5.58)$ & $4.40(3.35-5.62)$ & $4.36(3.31-5.55)$ & $4.28(3.29-5.40)$ & $4.24(3.24-5.43)$ \\
\hline Kenya & $9.31(7.61-11.33)$ & $9.22(7.53-11.33)$ & $9.08(7.42-11.08)$ & $8.76(7.10-10.73)$ & $8.63(7.11-10.51)$ \\
\hline Lao PDR & $17.13(12.86-24.17)$ & $16.22(12.19-22.38)$ & $15.98(12.05-21.95)$ & $14.52(10.99-19.54)$ & $14.11(10.76-18.78)$ \\
\hline Malawi & $6.64(4.67-9.18)$ & $6.44(4.59-8.86)$ & $6.33(4.45-8.72)$ & $6.00(4.12-8.24)$ & $5.89(4.14-8.10)$ \\
\hline Pakistan & $5.16(4.18-6.25)$ & $5.09(4.16-6.14)$ & $5.00(4.09-6.11)$ & $4.86(3.97-5.86)$ & $4.82(3.94-5.80)$ \\
\hline Philippines & $13.99(11.64-17.01)$ & $13.65(11.32-16.49)$ & $13.44(11.18-16.42)$ & $13.13(10.94-15.96)$ & $12.89(10.71-15.53)$ \\
\hline Tanzania & $5.73(4.23-7.60)$ & $5.59(4.18-7.19)$ & $5.52(4.16-7.09)$ & $5.29(3.94-6.87)$ & $5.23(3.90-6.84)$ \\
\hline Uganda & $9.42(7.24-11.95)$ & $9.26(7.14-11.68)$ & $9.11(7.17-11.43)$ & $8.72(6.83-11.03)$ & $8.55(6.66-10.75)$ \\
\hline Vietnam & $7.38(5.47-9.68)$ & $7.20(5.34-9.52)$ & $6.99(5.29-9.18)$ & $6.50(4.98-8.36)$ & $6.47(4.89-8.35)$ \\
\hline Zambia & $5.23(4.18-6.40)$ & $5.18(4.12-6.38)$ & $5.10(4.10-6.32)$ & $4.98(3.98-6.12)$ & $4.93(3.98-6.04)$ \\
\hline \multicolumn{6}{|l|}{ Duration of symptomatic TB } \\
\hline Cambodia & $8.24(6.68-9.98)$ & $8.15(6.61-9.78)$ & $8.08(6.68-9.69)$ & $7.74(6.38-9.27)$ & $7.75(6.39-9.24)$ \\
\hline Ethiopia & $4.92(3.81-6.22)$ & $4.93(3.84-6.19)$ & $4.88(3.77-6.07)$ & $4.78(3.70-6.02)$ & $4.78(3.74-5.96)$ \\
\hline Kenya & $9.48(8.03-11.15)$ & $9.44(7.95-11.14)$ & $9.27(7.83-10.91)$ & $8.89(7.63-10.30)$ & $8.89(7.58-10.39)$ \\
\hline Lao PDR & $27.69(22.11-36.99)$ & $26.46(21.24-34.63)$ & $25.42(20.58-32.65)$ & $21.60(18.02-26.91)$ & $21.56(17.92-26.49)$ \\
\hline Malawi & $15.77(12.80-19.43)$ & $15.46(12.49-18.92)$ & $15.05(12.21-18.43)$ & $14.13(11.72-17.01)$ & $14.11(11.54-17.05)$ \\
\hline Pakistan & $8.72(7.55-10.02)$ & $8.67(7.56-9.97)$ & $8.49(7.43-9.75)$ & $8.20(7.15-9.40)$ & $8.22(7.20-9.41)$ \\
\hline Philippines & $9.23(7.89-10.80)$ & $9.13(7.79-10.68)$ & $8.99(7.70-10.51)$ & $8.69(7.42-10.05)$ & $8.67(7.49-10.05)$ \\
\hline Tanzania & $10.87(8.91-13.13)$ & $10.70(8.75-12.94)$ & $10.51(8.62-12.73)$ & $10.03(8.47-11.96)$ & $10.06(8.48-11.95)$ \\
\hline Uganda & $10.53(8.48-12.89)$ & $10.40(8.33-12.70)$ & $10.16(8.30-12.35)$ & $9.66(7.98-11.61)$ & $9.61(7.92-11.47)$ \\
\hline Vietnam & $16.20(13.52-19.43)$ & $15.91(13.22-19.11)$ & $15.46(13.00-18.56)$ & $14.21(12.02-16.73)$ & $14.26(12.09-16.81)$ \\
\hline Zambia & $8.38(7.17-9.79)$ & $8.35(7.11-9.69)$ & $8.18(7.01-9.47)$ & $7.96(6.85-9.22)$ & $7.95(6.83-9.19)$ \\
\hline \multicolumn{6}{|l|}{ Case-detection ratio } \\
\hline Cambodia & $71 \%(59 \%-86 \%)$ & $69 \%(58 \%-83 \%)$ & $68 \%(57 \%-82 \%)$ & $66 \%(55 \%-79 \%)$ & $64 \%(54 \%-76 \%)$ \\
\hline Ethiopia & $90 \%(83 \%-97 \%)$ & $90 \%(83 \%-97 \%)$ & $89 \%(82 \%-96 \%)$ & $87 \%(80 \%-94 \%)$ & $87 \%(80 \%-93 \%)$ \\
\hline Kenya & $74 \%(63 \%-85 \%)$ & $73 \%(63 \%-83 \%)$ & $72 \%(62 \%-82 \%)$ & $69 \%(60 \%-79 \%)$ & $68 \%(59 \%-78 \%)$ \\
\hline Lao PDR & $28 \%(22 \%-38 \%)$ & $27 \%(21 \%-35 \%)$ & $26 \%(21 \%-35 \%)$ & $24 \%(19 \%-31 \%)$ & $23 \%(19 \%-30 \%)$ \\
\hline Malawi & $71 \%(59 \%-84 \%)$ & $69 \%(57 \%-82 \%)$ & $68 \%(56 \%-80 \%)$ & $64 \%(53 \%-75 \%)$ & $63 \%(52 \%-74 \%)$ \\
\hline Pakistan & $80 \%(72 \%-89 \%)$ & $79 \%(71 \%-88 \%)$ & $78 \%(70 \%-86 \%)$ & $76 \%(68 \%-84 \%)$ & $75 \%(67 \%-83 \%)$ \\
\hline Philippines & $56 \%(48 \%-66 \%)$ & $55 \%(47 \%-64 \%)$ & $54 \%(46 \%-63 \%)$ & $53 \%(46 \%-62 \%)$ & $52 \%(45 \%-60 \%)$ \\
\hline Tanzania & $74 \%(64 \%-83 \%)$ & $72 \%(63 \%-82 \%)$ & $71 \%(62 \%-80 \%)$ & $68 \%(59 \%-77 \%)$ & $67 \%(59 \%-76 \%)$ \\
\hline Uganda & $68 \%(58 \%-79 \%)$ & $67 \%(57 \%-77 \%)$ & $66 \%(56 \%-76 \%)$ & $63 \%(54 \%-73 \%)$ & $62 \%(53 \%-71 \%)$ \\
\hline Vietnam & $67 \%(55 \%-81 \%)$ & $66 \%(54 \%-78 \%)$ & $63 \%(53 \%-75 \%)$ & $59 \%(50 \%-69 \%)$ & $59 \%(49 \%-69 \%)$ \\
\hline Zambia & $84 \%(74 \%-93 \%)$ & $82 \%(74 \%-92 \%)$ & $81 \%(73 \%-90 \%)$ & $79 \%(71 \%-88 \%)$ & $78 \%(70 \%-87 \%)$ \\
\hline \multicolumn{6}{|l|}{ Incidence rate, per 100,000} \\
\hline Cambodia & $319(261-380)$ & $331(272-389)$ & $333(276-393)$ & $345(285-406)$ & $353(296-415)$ \\
\hline Ethiopia & $163(151-176)$ & $164(152-177)$ & $165(153-179)$ & $168(156-183)$ & $170(157-185)$ \\
\hline Kenya & $337(290-388)$ & $342(295-393)$ & $346(300-398)$ & $359(311-412)$ & $365(317-418)$ \\
\hline Lao PDR & $511(370-644)$ & $537(397-675)$ & $545(404-682)$ & $595(454-743)$ & $609(468-758)$ \\
\hline
\end{tabular}




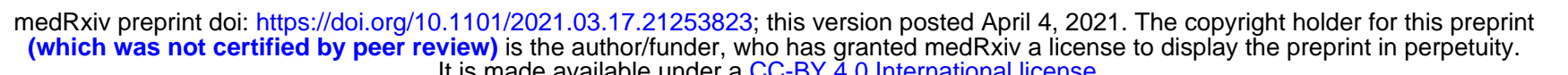

\begin{tabular}{r|ccccc} 
Malt is made avalable under a CC-BY & $198(165-239)$ & $204(170-245)$ & $208(175-250)$ & $222(186-265)$ & $224(189-268)$ \\
Pakistan & $270(243-301)$ & $274(246-306)$ & $279(250-309)$ & $287(258-319)$ & $290(262-321)$ \\
Philippines & $866(733-1,010)$ & $885(751-1,027)$ & $897(760-1,040)$ & $916(779-1,059)$ & $932(798-1,076)$ \\
Tanzania & $283(248-323)$ & $288(253-330)$ & $293(259-334)$ & $306(269-349)$ & $309(272-352)$ \\
Uganda & $326(280-381)$ & $332(285-387)$ & $336(289-393)$ & $353(303-410)$ & $359(308-416)$ \\
Vietnam & $203(167-243)$ & $208(173-248)$ & $215(179-254)$ & $230(194-272)$ & $232(197-275)$ \\
Zambia & $402(360-450)$ & $408(365-455)$ & $413(371-460)$ & $425(382-472)$ & $430(386-476)$ \\
\hline
\end{tabular}

$\mu$ : background mortality based on the World Population Perspects, 2016 for Kenya and 2019 for Blantyre (Malawi) 


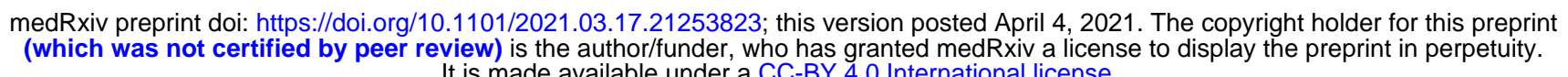

Table 4-table supplement 3 Sensitivity analysis: definition of symptomatic TB

\begin{tabular}{|c|c|c|c|c|c|}
\hline \multirow[b]{2}{*}{ Symptomatic } & \multicolumn{2}{|c|}{ Blantyre } & \multicolumn{3}{|c|}{ Kenya } \\
\hline & Cough $>=2$ weeks & Definition 2 & Cough $>=2$ weeks & Definition 2 & Definition 3 \\
\hline \multicolumn{6}{|l|}{ All TB regardless of symptomatic or not } \\
\hline Time to symptom onset, month & $4.45(2.70-6.65)$ & $2.96(1.56-4.73)$ & $8.80(7.17-10.68)$ & $6.00(4.71-7.53)$ & $1.43(0.93-2.09)$ \\
\hline Time to notification, month & $8.87(6.42-11.67)$ & $8.55(6.20-11.16)$ & $\begin{array}{c}17.74(15.37- \\
20.41)\end{array}$ & $\begin{array}{c}17.32(15.06- \\
20.04)\end{array}$ & $\begin{array}{c}16.25(13.96- \\
18.91)\end{array}$ \\
\hline Case-detection ratio & $85 \%(77 \%-93 \%)$ & $85 \%(77 \%-92 \%)$ & $69 \%(59 \%-79 \%)$ & $68 \%(59 \%-78 \%)$ & $68 \%(58 \%-77 \%)$ \\
\hline Incidence rate, per 100,000 & $382(346-427)$ & $383(347-427)$ & $358(311-414)$ & $363(317-417)$ & $365(321-421)$ \\
\hline \multicolumn{6}{|l|}{ All symptomatic TB } \\
\hline Time to notification, month & $4.40(2.50-6.39)$ & $5.60(3.71-7.78)$ & $8.91(7.61-10.39)$ & $11.30(9.80-13.09)$ & $\begin{array}{c}14.81(12.69- \\
17.29)\end{array}$ \\
\hline Case-detection ratio & $91 \%(85 \%-96 \%)$ & $89 \%(81 \%-94 \%)$ & $80 \%(73 \%-87 \%)$ & $75 \%(68 \%-83 \%)$ & $69 \%(60 \%-78 \%)$ \\
\hline Incidence rate, per 100,000 & $357(334-387)$ & $367(340-401)$ & $308(284-337)$ & $328(298-364)$ & $357(317-408)$ \\
\hline
\end{tabular}

Definition 2: cough $>=14$ days, hemoptysis, fever, weight loss, night sweats

Definition 3: cough >= 14 days, hemoptysis, fever, breathe shortness, hemoptysis, chest pains, night sweats, weight loss 